UCRL-ID-128950

\title{
Potential for Radionuclide Immobilization in the EBS/NFE: Solubility Limiting Phases for Neptunium, Plutonium, and Uranium
}

Joseph A. Rard

October 1997

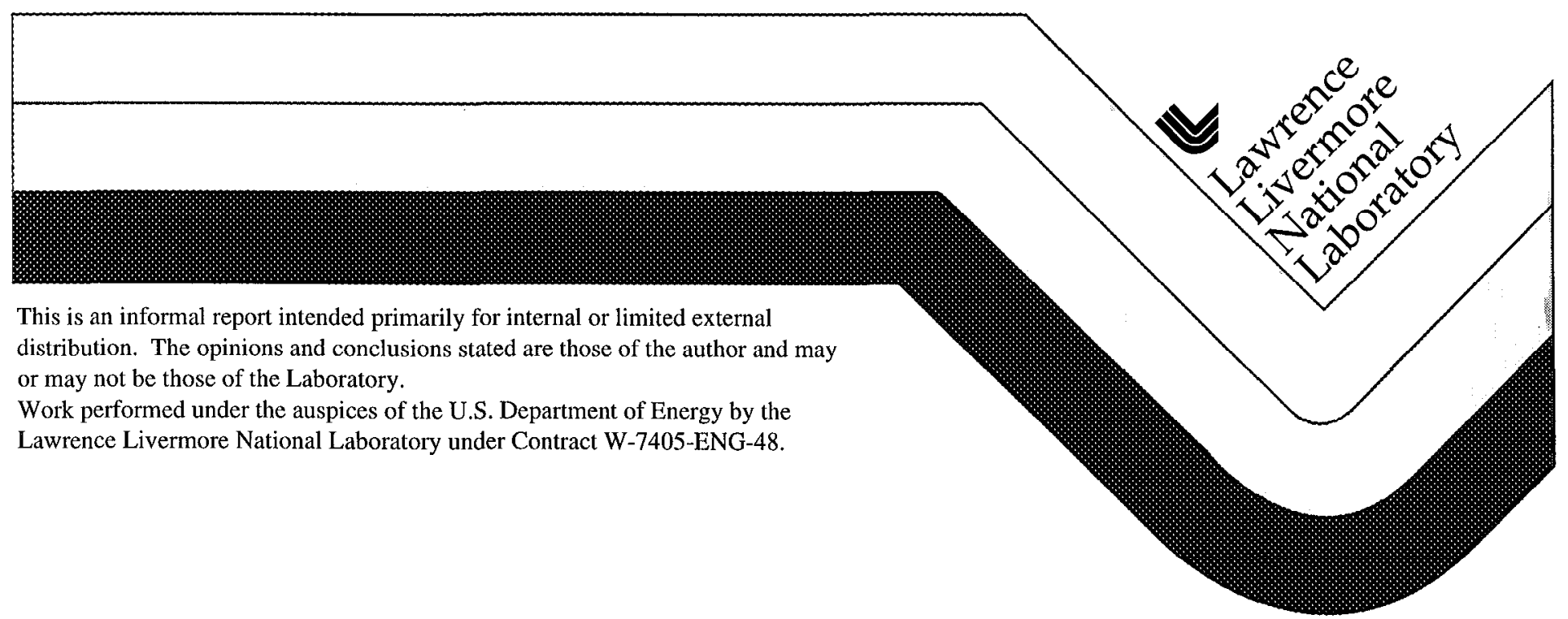




\section{DISCLAIMER}

This document was prepared as an account of work sponsored by an agency of the United States Government. Neither the United States Government nor the University of California nor any of their employees, makes any warranty, express or implied, or assumes any legal liability or responsibility for the accuracy, completeness, or usefulness of any information, apparatus, product, or process disclosed, or represents that its use would not infringe privately owned rights. Reference herein to any specific commercial product, process, or service by trade name, trademark, manufacturer, or otherwise; does not necessarily constitute or imply its endorsement, recommendation, or favoring by the United States Government or the University of California. The views and opinions of authors expressed herein do not necessarily state or reflect those of the United States Government or the University of California, and shall not be used for advertising or product endorsement purposes.

This report has been reproduced directly from the best available copy.

Available to DOE and DOE contractors from the Office of Scientific and Technical Information P.O. Box 62, Oak Ridge, TN 37831

Prices available from (423) 576-8401

Available to the public from the National Technical Information Service

U.S. Department of Commerce 5285 Port Royal Rd.,

Springfield, VA 22161 


\section{Letter Report \\ Milestone SPL3EM4}

Potential for Radionuclide Immobilization in the EBS/NFE: Solubility Limiting Phases for Neptunium, Plutonium, and Uranium

$$
\text { Joseph A. Rard }
$$

Geosciences and Environmental Technologies, Environmental Programs Directorate, Lawrence Livermore National Laboratory, University of California, Livermore, CA 94550

Retardation and dispersion in the far field of radionuclides released from the engineered barrier system/near field environment (EBS/NFE) may not be sufficient to prevent regulatory limits being exceeded at the accessible environment. Herice, a greater emphasis must be placed on retardation and/or immobilization of radionuclides in the EBS/NFE. The present document represents a survey of radionuclide-bearing solid phases that could potentially form in the EBS/NFE and immobilize radionuclides released from the waste package and significantly reduce the source term. A detailed literature search was undertaken for experimental solubilities of the oxides, hydroxides, and various salts of neptunium, plutonium, and uranium in aqueous solutions as functions of $\mathrm{pH}$, temperature, and the concentrations of added electrolytes. Numerous solubility studies and reviews were identified and copies of most of the articles were acquired. However, this project was only two months in duration, and copies of some the identified solubility studies could not be obtained at short notice.

The results of this survey are intended to be used to assess whether a more detailed study of identified low-solubility phase(s) is warranted, and not as a data base suitable for predicting radionuclide solubility. The results of this survey may also prove useful in a preliminary evaluation of the efficacy of incorporating chemical additives to the EBS/NFE that will enhance radionuclide immobilization. 


\section{Neptunium}

Speciation diagram calculations [Allard, Kipatsi, and Liljezin, 1980; Eriksen, Ndalamba, et al., 1993; Kim, 1986; Martinot, 1978; Rees, 1985] using then available thermodynamic data bases indicate that dissolved species of $\mathrm{Np}$ (III), $N p(I V), N p(V), N p(V I)$, and $N p(V I I)$ can form in aqueous solutions.

However, $\mathrm{Np}$ (III) can exist only under very reducing conditions and at acidic pHs, and it is unlikely to be present in significant amounts under environmental conditions. Similarly, $N p(V I)$, which is present as the $\mathrm{NpO}_{2}^{2+}(\mathrm{aq})$ ion and its various hydrolyzed and complexed species in aqueous solutions, and $\mathrm{Np}(\mathrm{VII})$, which may exist as $\mathrm{NpO}_{3}^{+}$(aq) fand possibly as $\mathrm{NpO}_{5}^{3-}(\mathrm{aq})$ in concentrated sodium hydroxide [Martinot, 1978]\}, occur only under oxidizing conditions. Above a $\mathrm{pH}$ of 8 or 9 the formation of $\mathrm{NpO}_{2}^{2+}(\mathrm{aq})$ ion is more favored, especially when carbonate is present [Newton and Sullivan, 1985]. The formal potential of the $\mathrm{NpO}_{3}^{+}(\mathrm{aq}) / \mathrm{NpO}_{2}^{2+}(\mathrm{aq})$ redox couple in 1 molar acid occurs around 2.0 V [Martinot, 1978; Martinot and Fuger, 1985], which is above the water stability field and thus $N p(V I I)$ will be reduced by water. Some solubility studies are available for $\mathrm{Np}$ (VI) [Kato, Kimura, et al., 1996; Moskvin, 1971; Novak, Nitsche, et al., 1996] but the conditions required to prepare these solutions, i.e., oxidation with ozone [Kato, Kimura, et al., 1996] or electrochemical oxidation [Novak, Nitsche, et al., 1996], indicate that $\mathrm{Np}(\mathrm{VI})$ species will also not form in significant amounts for aqueous solutions at equilibrium under environmental conditions.

Published speciation calculations using available thermodynamic data bases indicate that aqueous solutions and solid compounds of $\mathrm{Np}(\mathrm{V})$ will be present under most typical environmental conditions, and that $\mathrm{Np}(\mathrm{IV})$ will be more important under fairly reducing conditions especially at low values of the pH [Allard, Kipatsi, and Liljezin, 1980; Eriksen, Ndalamba, et al., 1993 Kim, 1986; Martinot, 1978]. Long-term solubility studies seem to confirm this conclusion. For example, solutions of $\mathrm{Np}(\mathrm{V})$ at $\mathrm{pH}=6$ and at 8.5 with an atmosphere of $\mathrm{Ar}-\mathrm{CO}_{2}$ mixtures, equilibrated at 298 and $333 \mathrm{~K}$ with solid crystalline phase(s) of uncertain composition, contained $100 \% \mathrm{~Np}(\mathrm{~V})$ in the solution phase at equilibrium [Nitsche, 1987]. Similar solubility experiments with solutions initially containing $N p(I V)$ and $N p(V)$, but involving an atmosphere of $\mathrm{CO}_{2}$-free $\mathrm{Ar}$ and 5.3 molar $\mathrm{NaCl}$, were performed for periods ranging up to 2500 days [Silber, Nitsche, et al., 1994] yielded solubilities at 
alkaline $\mathrm{pHs}$ that were converging at long equilibration times. According to the authors, this probably indicates that radiolysis products in the $N p$ (IV) solutions are gradually converting the solutions of $N p(I V)$ to $N p(V)$. In moderately to very concentrated high-chloride synthetic brines [Novak, Nitsche, et al., 1996] at nearly neutral pH, electrolytically-generated solutions of $\mathrm{Np}(\mathrm{VI})$ underwent $<7 \%$ reduction to $\mathrm{Np}(\mathrm{V})$ but still contained mainly $\mathrm{Np}(\mathrm{VI})$ even after solubility experiments lasting 734 days. These solutions were maintained in an atmosphere of $\mathrm{Ar}-\mathrm{O}_{2}-\mathrm{CO}_{2}$ mixtures containing about $21 \% \mathrm{O}_{2}(\mathrm{~g})$. The solid phase observed at the end of these solubility experiments was $\mathrm{KNpO}_{2} \mathrm{CO}_{3} \cdot \mathrm{xH}_{2} \mathrm{O}(\mathrm{s})$ which contains $\mathrm{Np}(\mathrm{V})$. However, in that same study and under similar experimental conditions, solutions of $\mathrm{Np}(\mathrm{V})$ equilibrated with a solid phase of $\mathrm{KNpO}_{2} \mathrm{CO}_{3} \cdot \mathrm{xH}_{2} \mathrm{O}(\mathrm{s})$ contained only $N p(V)$ in the solution phase after equilibrations ranging from 543 to 763 days, which implies that $N p(V)$ is not oxidized to $N p(V I)$ in these oxygen-saturated solutions. The conclusion of Andersson [Andersson, 1989] that $\mathrm{Np}(\mathrm{OH})_{4}(\mathrm{~s})$ is the solubility limiting phase under both oxidizing and reducing conditions probably resulted from use of an incomplete thermodynamic data base.

The studies described in the preceding paragraph imply that aqueous solutions, initially containing $N p(I V)$ and $N p(V)$, will contain predominantly or entirely $\mathrm{Np}(\mathrm{V})$ after long-term equilibrations with hydrous oxides or neptunium carbonate phases when these equilibrations are performed in an essentially oxygen-free non-reducing atmosphere or with an oxygen-rich oxidizing atmosphere. There is no observed significant oxidation of $N p(V)$ to $\mathrm{Np}(\mathrm{VI})$, but if $\mathrm{Np}(\mathrm{VI})$ is generated by electrolytic or chemical oxidation, it can persist for long periods in the presence of oxygen or ozone.

Solubility studies have been performed for the hydrous oxide of $\mathrm{Np}$ (IV), which we shall write as $\mathrm{NpO}_{2} \cdot \mathrm{xH}_{2} \mathrm{O}(\mathrm{s})$. References for these solubility studies are [Eriksen, Ndalamba, et al., 1993; Ewart, 1985; Krupka, Rai, et al., 1985; Moskvin, 1971b; Nakayama, Yamaguchi, and Sekine, 1996; Pratopo, Moriyama, and Higashi, 1990; Rai and Ryan, 1985; Rai, Swanson, and Ryan, 1987]. Neptunium was maintained as $\mathrm{Np}$ (IV) by addition of strong reducing agents to the solution, or by equilibrating them against a solid reducing agent. For example, Eriksen, Ndalamba, et al. [1993] used the aqueous redox buffers $\mathrm{S}_{2} \mathrm{O}_{4}^{2-} / \mathrm{SO}_{3}^{2-}$ and $\mathrm{S}_{4} \mathrm{O}_{6}^{2-} / \mathrm{S}_{2} \mathrm{O}_{3}^{2-}$, Moskvin [1971b] used hydrazine nitrate, Nakayama, Yamaguchi, and Sekine [1996] used copper metal or $\mathrm{Na}_{2} \mathrm{~S}_{2} \mathrm{O}_{4}$ (i.e.., the $\mathrm{S}_{2} \mathrm{O}_{4}^{2-} / \mathrm{SO}_{3}^{2-}$ redox buffer), Pratopo, Moriyama, and Higashi [1990] used 
hydrazine chloride, and Rai and co-workers [Krupka, Rai, et al., 1985; Rai and Ryan, 1985] used $\mathrm{Na}_{2} \mathrm{~S}_{2} \mathrm{O}_{4}$, metallic iron, or metallic zinc. All of the above reducing agents were quite effective in maintaining neptunium as $\mathrm{Np}$ (IV). However, Rai and Ryan [1985] found that metallic lead and metallic nickel were not sufficiently strong reducing agents to perform this reduction, and Rai, Swanson, and Ryan [1987] found that the $\mathrm{Cu}(\mathrm{I}) / \mathrm{Cu}(\mathrm{II})$ redox buffer yielded a mixture of $N p(I V)$ and $N p(V)$ at equilibrium. Any reducing agent or redox buffer that produces solutions with Eh $<-0.3 \mathrm{~V}$ should be satisfactory for keeping $\mathrm{Np}$ present in the +4 valence state.

Solubilities of $\mathrm{NpO}_{2} \mathrm{OH}(\mathrm{s})$ have been reported as a function of $\mathrm{pH}$ in several studies [Moskvin, 1971b; Roberts, Silber, et al., 1996; Sevost'yanova and Khalturin, 1976; Silber, Nitsche, et al., 1994]. No reducing agents or redox buffers were added to these solutions to control the oxidation of the neptunium during the solubility experiments. These solutions are slow to reach equilibrium at alkaline $\mathrm{pHs}$, presumably due to slow hydrolysis reactions in the aqueous phase [Silber, Nitsche, et al., 1994]. Long term solubility experiments [Roberts, Silber, et al., 1996; Silber, Nitsche, et al., 1994] indicate an equilibrium or steady state concentration of $\mathrm{Np}(\mathrm{V})$ of about $10^{-6}$ to $10^{-5}$ molar for $\mathrm{pH}=9$ to 13 and about $10^{-2}$ molar at $\mathrm{pH}=7$.

A much greater number of studies have been performed of the solubility of $\mathrm{Np}(\mathrm{V})$ in the presence of carbonate [Lemire, Boyer, and Campbell, 1993; Marx and Keiling, 1989; Maya, 1983; Neck, Runde, et al., 1994; Nitsche, 1987; Nitsche, 1991; Novak, Nitsche, et al., 1996; Simakin, 1977; Ueno and Sato, 1975; Visyashcheva, Volkov, et al., 1974]. No reducing agents or redox buffers were added to these solutions to control the oxidation state of the neptunium during the solubility experiments. At low carbonate concentrations the solid phase remains $\mathrm{NpO}_{2} \mathrm{OH}(\mathrm{s})$, but at high carbonate concentrations solid phases such as $\mathrm{NaNpO}_{2} \mathrm{CO}_{3} \cdot \mathrm{xH}_{2} \mathrm{O}$ (s) [Lemire, Boyer, and Campbell, 1993; Maya, 1983; Neck, Runde, et al., 1994; Ueno and Sato, 1975], $\mathrm{KNpO}_{2} \mathrm{CO}_{3} \cdot \mathrm{XH}_{2} \mathrm{O}(\mathrm{s})$ [Novak, Nitsche, et al., 1996], $\mathrm{Na}_{3} \mathrm{NpO}_{2}\left(\mathrm{CO}_{3}\right)_{2} \cdot \times \mathrm{H}_{2} \mathrm{O}(\mathrm{s})$ [Lemire, Boyer, and Campbell, 1993; Simakin, 1977] and $\mathrm{K}_{3} \mathrm{NpO}_{2}\left(\mathrm{CO}_{3}\right)_{2} \cdot \mathrm{xH}_{2} \mathrm{O}(\mathrm{s})$ [Visyashcheva, Volkov, et al., 1974] were formed. A variety of mixed oxy- or hydroxycarbonate complexes of neptunium form in these saturated solutions, and their stability constants have been summarized in several reviews [Clark, Hobart, and Neu, 1995; Kim, 1986; Neck, Runde, et al., 1994; Newton and Sullivan, 1985]. Addition of carbonate at concentrations of up to about $10^{-4}$ molar cause the solubility of 
$\mathrm{Np}(\mathrm{V})$ to decrease to a minimum solubility, but at higher carbonate concentrations there is a rapid increase in solubility with increasing carbonate concentration [Lemire, Boyer, and Campbell, 1993; Maya, 1983; Neck, Runde, et al., 1994; Ueno and Sato, 1975]. These solubility changes with carbonate concentration are due to changes in aqueous speciation and the switch over in the equilibrium solid phase from $\mathrm{NpO}_{2} \mathrm{OH}(\mathrm{s})$ to other phases such as $\mathrm{NaNpO}_{2} \mathrm{CO}_{3} \cdot \mathrm{xH}_{2} \mathrm{O}(\mathrm{s})$. Minimum solubilities are also observed at $\mathrm{pHs}$ around 7 at high electrolyte concentrations [Neck, Runde, et al., 1994].

The solubility of $\mathrm{NpO}_{2} \cdot \times \mathrm{H}_{2} \mathrm{O}(\mathrm{s})$ in carbonate-free water or at very low carbonate concentrations in the presence of reducing agents is about $10^{-8}$ molar and is independent of $\mathrm{pH}$ from about $\mathrm{pH}=6$ to 13 [Eriksen, Ndalamba, et al., 1993; Ewart, 1985; Krupka, Rai, et al., 1985; Nakayama, Yamaguchi, and Sekine, 1996; Rai and Ryan, 1985]. However, the solubility is much higher at lower pHs: $1.2 \times 10^{-2}$ at $\mathrm{pH}=3.00$ to $4.2 \times 10^{-2}$ at $\mathrm{pH}=1.20$ [Moskvin, 1971].

Carbonate complexes in neutral to alkaline solutions increase the solubility of $\mathrm{NpO}_{2} \cdot \mathrm{xH}_{2} \mathrm{O}$ (s) by one to two orders of magnitude [Eriksen, Ndalamba, et al., 1993; Pratopo, Moriyama, and Higashi, 1990], depending on $\mathrm{pH}$ and carbonate concentration, owing to the formation of mixed hydroxycarbonate complexes.

There are very few studies that report solubilities for solutions of $\mathrm{Np}(\mathrm{VI})$. Solubilities of "neptunyl hydroxide" were reported that range from $2.3 \times 10^{-2}$ to $6.3 \times 10^{-4}$ molar over the $\mathrm{pH}$ range of 3.5 to 8.5 [Moskvin, 1971] and of $\mathrm{NpO}_{3} \cdot \mathrm{xH}_{2} \mathrm{O}(\mathrm{s})$ were reported graphically to be about $10^{-2}$ to $10^{-3}$ molar from $\mathrm{pH} \approx 4.2$ to 4.5 at low carbonate concentrations [Kato, Kimura, et al., 1996]. Solubilities of $\mathrm{Np}(\mathrm{VI})$ in the presence of the solid phase $\mathrm{KNpO}_{2} \mathrm{CO}_{3} \cdot \mathrm{xH}_{2} \mathrm{O}(\mathrm{s})$, formed by partial reduction of $\mathrm{Np}(\mathrm{VI})$, were from $3.2 \times 10^{-4}$ to $8.3 \times 10^{-4}$ molar for pHs of 7.1 to 7.5 in high-chloride concentrated brines containing carbonate [Novak, Nitsche, et al., 1996]. In the presence of an atmosphere of $80 \%$ $\mathrm{CO}_{2} / 20 \% \mathrm{O}_{2}, \mathrm{NpO}_{2} \mathrm{CO}_{2}$ (s) was observed to be the solubility limiting phase [Kato, Kimura, 1996]. These solubilities are about 4 to 6 orders of magnitude larger than those of $\mathrm{Np}(\mathrm{IV})$ under comparable conditions.

No solubilities were located for neptunium silicates. However, based on anologies with uranyl silicates [Moll, Geipel., et al., 1996; Nguyen, Silva, et al., 1992; Puidgomènech and Bruno, 1988] we expect $\left(\mathrm{NpO}_{2}\right)_{2} \mathrm{SiO}_{4} \cdot \times \mathrm{H}_{2} \mathrm{O}(\mathrm{s})$ to be comparable in solubility to $\mathrm{NpO}_{3} \cdot \mathrm{xH}_{2} \mathrm{O}(\mathrm{s})$. Andersson [Andersson, 1989] cited values for the solubility product of $\mathrm{NpO}_{2}\left(\mathrm{HPO}_{4}\right)(\mathrm{s}), \mathrm{K}=10^{-13}$, and of $\left(\mathrm{NpO}_{2}\right)_{3}\left(\mathrm{PO}_{4}\right)(\mathrm{s}), \mathrm{K}=10^{-50}$. It is likely that the second formula is a misprint for 
$\left(\mathrm{NpO}_{2}\right)_{3}\left(\mathrm{PO}_{4}\right)_{2}(\mathrm{~s})$, in which case these solubility products for the plutonium phosphates are nearly identical to those given for their uranium analogues. These solubility products for the neptunyl phosphates may simply be estimates based on the uranyl phosphate data. The first solubility product indicates that $\mathrm{NpO}_{2}\left(\mathrm{HPO}_{4}\right)$ (s) should be quite soluble. Stability constants [Patil, Ramakrishna, and Ramaniah, 1978; Moskvin and Peretrukhin, 1964] and Gibbs energies of formation [Lemire and Garisto, 1989] have been reported for various $\mathrm{HPO}_{4}^{2-}$ and $\mathrm{H}_{2} \mathrm{PO}_{4}^{-}$complexes of neptunium, and indicate that the presence of these complexes should considerably enhance the solubility of neptunium.

Examination of the solubility and redox information summarized in the preceding paragraphs indicates that minimum solubilities for neptunium are favored by $\mathrm{pH} \approx 6$ to 13 , by very low carbonate concentrations, and by reducing conditions with Eh $<-0.3 \mathrm{~V}$. Less reducing conditions and acidic $\mathrm{pHs}$ favor increased solubility, as do alkaline conditions when high concentrations of carbonate are present.

It is suggested that two of the three conditions for lower solubilities of neptunium in a repository can be met by adding materials that compete for carbonate from infiltrating groundwater, by forming sparingly soluble carbonate precipitates, and which increase the alkalinity. One possibility is to add mixtures of gypsum $\left(\mathrm{CaSO}_{4} \cdot 2 \mathrm{H}_{2} \mathrm{O}\right)$ or anhydrite $\left(\mathrm{CaSO}_{4}\right)$ and lime $(\mathrm{CaO})$. These would raise the $\mathrm{pH}$ into a favorable range as these materials dissolve, and would provide sources of calcium ions to precipitate most of the dissolved carbonate/bicarbonate as calcite $\left(\mathrm{CaCO}_{3}\right)$. Jackson [Jackson, 1996] has proposed the use of $\mathrm{MgO}$ (periclase) for a similar function. The calcium sources could also give precipitation of hydroxy apatite, $\mathrm{Ca}_{10}\left(\mathrm{PO}_{4}\right)_{6}(\mathrm{OH})_{2}$, or calcium phosphate, $\mathrm{Ca}_{3}\left(\mathrm{PO}_{4}\right)_{2}$, to help sequester the phosphate from the groundwater. Solubilities of $\mathrm{Np}$ (IV) of about $10^{-8}$ molar and lower have been observed in cement-equilibrated waters, which indicates that this alkaline system would also be satisfactory for controlling $\mathrm{pH}$ [Ewart, Gore, and Williams, 1985; Ewart, Howse, et al., 1986].

Reducing conditions with $\mathrm{Eh}<-0.3 \mathrm{~V}$ are even more critical for lowering the solubility of neptunium by formation of $\mathrm{Np}$ (IV) solutions and solid phases. Some of the methods described above for reducing the dissolved $\mathrm{Np}(\mathrm{V})$ to $\mathrm{Np}(\mathrm{IV})$ and keeping it in that valence state involved use of hydrazine or the $\mathrm{S}_{2} \mathrm{O}_{4}^{2-} / \mathrm{SO}_{3}^{2-}$ and $\mathrm{S}_{4} \mathrm{O}_{6}^{2-} / \mathrm{S}_{2} \mathrm{O}_{3}^{2-}$ redox buffers. It would be very 
difficult to control the concentrations of these chemical species for long periods of time (and thus the Eh of these solutions) in a repository situation due to their high solubilities in water and the complicated chemistry of the sulfur-oxygen-water system with its numerous redox couples. Use of one of the metal powders described above ( $\mathrm{Fe}, \mathrm{Zn}$, or $\mathrm{Cu}$ ), added in large excess to the backfill material, could produce the desired highly reducing conditions. Corrosion of the waste canister overpack would also contribute to the desired reducing environment close to the waste canister. However, generation of $\mathrm{H}_{2}(\mathrm{~g})$ upon overpack or metal powder dissolution at acidic or alkaline $\mathrm{pHs}$ could be a problem in certain waste repository configurations. Another possibility would be to make use of the $\Gamma / \Gamma_{3}$ redox buffer for which $\mathrm{E} \approx-0.5 \mathrm{~V}$; this would avoid problems with gas generation since this involves a $\mathrm{pH}$ independent redox reaction. A sparingly soluble salt such as CuI might make a suitable additive for slow release of iodide, although considerable amounts may be required to maintain reducing conditions for long periods of time.

\section{Plutonium}

Speciation diagram calculations [Allard, Kipatsi, and Liljezin, 1980; 1993 Kim, 1986; Martinot, 1978; Puigdomènech and Bruno, 1991; Rai, Serne, and Swanson, 1980; Yamaguchi, Sakamoto, and Ohnuki, 1994] using then available thermodynamic data bases indicate that dissolved species of $\mathrm{Pu}(\mathrm{III})$, $\mathrm{Pu}(\mathrm{IV}), \mathrm{Pu}(\mathrm{V})$, and $\mathrm{Pu}(\mathrm{VI})$ can form in aqueous solutions. All of these valence states can occur in the $\mathrm{Eh}, \mathrm{pH}$ range of natural waters [Kim, 1986] and thus solutions of all of these ions are important for controlling solubilities. The valence state $\mathrm{Pu}(\mathrm{VII})$ is also known in aqueous solution, but it forms only under very oxidizing conditions [Delegard, 1987, Martinot and Fuger, 1985] and is reduced by water to $\mathrm{Pu}(\mathrm{VI})$.

Long-term solubility studies are consistent with this conclusion. Nitsche [Nitsche, 1987] found that for solutions equilibrated at $\mathrm{pH}=6$ with a precipitated solid phase, $\mathrm{Pu}(\mathrm{V})$ predominated at "equilibrium" with slightly smaller amounts of $\mathrm{Pu}(\mathrm{VI})$ being present, but at $\mathrm{pH}=8.5 \mathrm{Pu}(\mathrm{IV})$ predominated over $\mathrm{Pu}(\mathrm{V})$ in the solutions. These experiments were done at 298 and $333 \mathrm{~K}$ with $120 \mathrm{ppm}$ carbonate in the solutions, and the solid phase was reported to be $\mathrm{PuO}_{2} \cdot \mathrm{xH}_{2} \mathrm{O}(\mathrm{s})$ or a $\mathrm{Pu}(\mathrm{IV})$ colloid. In "J-13" groundwater [Nitsche, 1991], solutions equilibrated for lengthy periods at 298, 333, and $363 \mathrm{~K}$ yielded solid phases of "polymeric $\mathrm{Pu}(\mathrm{IV})$ and plutonium carbonates." The 
solution phases contained predominantly $\mathrm{Pu}(\mathrm{V})$, with major amounts of $\mathrm{Pu}(\mathrm{VI})$ and lesser amounts of $\mathrm{Pu}(\mathrm{III})$ and $\mathrm{Pu}(\mathrm{IV})$. Solutions equilibrated with a solid phase of $\mathrm{PuO}_{2} \cdot \times \mathrm{H}_{2} \mathrm{O}(\mathrm{s})$ at $295 \pm 2 \mathrm{~K}$ [Rai, 1984] were analyzed after being equilibrated for 5 days and after 83 days. After 5 days, $\mathrm{Pu}(\mathrm{III})+\mathrm{Pu}(\mathrm{IV})$ predominated for $0.55 \leq \mathrm{pH} \leq 1.20$ but for $1.50 \leq \mathrm{pH} \leq 4.30 \mathrm{Pu}(\mathrm{V})+\mathrm{Pu}(\mathrm{VI})$ were the predominant valence states. For the 83 day equilibration, $\mathrm{Pu}(\mathrm{IV}), \mathrm{Pu}(\mathrm{V})$, and $\mathrm{Pu}(\mathrm{VI})$ were detected at most $\mathrm{pHs}$. For $0.50 \leq \mathrm{pH} \leq 1.00 \mathrm{Pu}(\mathrm{IV})$ predominated, for $1.20 \leq \mathrm{pH} \leq 2.00 \mathrm{Pu}(\mathrm{V})$ predominated, but for $2.30 \leq \mathrm{pH} \leq$ $3.40 \mathrm{Pu}(\mathrm{V})$ and $\mathrm{Pu}(\mathrm{VI})$ were present in comparable amounts. At higher $\mathrm{pHs}$ of $3.70 \leq \mathrm{pH} \leq 4.90, \mathrm{Pu}(\mathrm{V})$ predominated over $\mathrm{Pu}(\mathrm{IV})$ but the amount present as $\mathrm{Pu}(\mathrm{VI})$ was not determined. Solubility experiments for $\mathrm{PuO}_{2} \cdot \mathrm{xH}_{2} \mathrm{O}(\mathrm{am})$ in 1 molar $\mathrm{HClO}_{4}(\mathrm{aq})$ at $293 \pm 1 \mathrm{~K}$ contained mainly $\mathrm{Pu}(\mathrm{IV})$ colloid and monomer after 45 days, along with small amounts of $\mathrm{Pu}(\mathrm{VI})$ [Kim and Kanellakopulos, 1989]. In that same study solutions equilibrated with $\mathrm{PuO}_{2}$ (cr) contained mainly $\mathrm{Pu}(\mathrm{III})$ with lesser amounts of monomeric $\mathrm{Pu}(\mathrm{IV})$ and a trace of $\mathrm{Pu}(\mathrm{VI})$.

Solubility experiments were also done with "H-17" brine [Nitsche, Roberts, et al., 1994], which is a predominantly a $\mathrm{NaCl}$ brine with $\mathrm{pH} \approx 7.1$. In these experiments, the plutonium was added to separate samples of the brine as $\mathrm{Pu}(\mathrm{III})$, as monomeric $\mathrm{Pu}(\mathrm{IV})$, as polymeric $\mathrm{Pu}(\mathrm{IV})$, as $\mathrm{Pu}(\mathrm{V})$, or as $\mathrm{Pu}(\mathrm{VI})$. The solutions were saturated with a gas mixture containing $\mathrm{Ar}-\mathrm{O}_{2}-\mathrm{CO}_{2}$. The various saturated solutions equilibrated in contact with the precipitated solid phase(s) for 328 to 342 days contained from 69 to $96 \% \mathrm{Pu}(\mathrm{VI})$, from 2 to $27 \%$ $\mathrm{Pu}(\mathrm{V})$, small amounts of monomeric $\mathrm{Pu}(\mathrm{IV})$, and very small amounts of $\mathrm{Pu}(\mathrm{III})$ and polymeric $\mathrm{Pu}(\mathrm{IV})$. The solid phases formed in contact with the solutions that were prepared from $\mathrm{Pu}(\mathrm{III})$ and monomeric $\mathrm{Pu}(\mathrm{IV})$ were crystalline but were not identified, whereas the solid phase that formed when $\mathrm{Pu}(\mathrm{V})$ or $\mathrm{Pu}(\mathrm{VI})$ were used to prepare the initial solution was probably $\mathrm{NaPuO}_{2} \mathrm{CO}_{3}(\mathrm{~s})$. Solubility experiments were reported [Felmy, Rai, et al., 1989] in which the solid phase was controlled to be $\mathrm{Pu}(\mathrm{OH})_{3}(\mathrm{~s})$ by addition of iron powder. This is the only one of the cited solubility studies for plutonium in which a reducing agent was used to control the valence of plutonium. These experiments were performed in an atmosphere of purified argon in solutions of distilled water and two types of brines. Values of Eh for these solutions ranged from -0.25 to $-0.37 \mathrm{~V}$. The $\mathrm{pHs}$ were adjusted by use of $\mathrm{HCl}$ and carbonate-free $\mathrm{NaOH}$. Solubilities were consistently higher in the brines than 
in the distilled water. The solubility of $\mathrm{Pu}(\mathrm{OH})_{3}(\mathrm{~s})$ was $\leq 1 \times 10^{-9}$ molar for $\mathrm{pH}$ $\approx 9$ to 13 , but increased rapidly at lower $\mathrm{pHs}$, reaching a value of about $1 \times 10^{-4}$ molar at $\mathrm{pH}=7$ in distilled water.

Rai and Ryan [Rai and Ryan, 1982] studied the solubilities of $238 \mathrm{PuO}_{2}(\mathrm{cr})$, of ${ }^{239} \mathrm{PuO}_{2}(\mathrm{cr})$, and of ${ }^{239} \mathrm{PuO}_{2} \cdot \times \mathrm{H}_{2} \mathrm{O}(\mathrm{am})$ in aqueous solutions for up to 1300 days. The solubilities of the two materials containing ${ }^{239} \mathrm{Pu}$ seemed to approach each other after long equilibrations, which indicated that the crystalline material slowly converted (because of reaction with the radiolysis products of water) to a less-crystalline or amorphous material. In contrast, the ${ }^{238} \mathrm{PuO}_{2}(\mathrm{cr})$ was converted into a colloidal hydrous oxide. The solubility of the polymeric $\mathrm{Pu}(\mathrm{IV})$ is intermediate between that of $\mathrm{PuO}_{2}(\mathrm{cr})$ and $\mathrm{PuO}_{2} \cdot \mathrm{xH}_{2} \mathrm{O}(\mathrm{am})$ [Puigdomènech and Bruno, 1991].

Clearly, in the absence of a redox potential control, solutions of plutonium in equilibrium with a solid plutonium hydrous oxide or carbonate phase will exist as mixture of various valence states, whose proportions will change with time, $\mathrm{pH}$, and carbonate concentration. Crystalline $\mathrm{PuO}_{2}(\mathrm{cr})$ evolves into $\mathrm{PuO}_{2} \cdot \mathrm{xH}_{2} \mathrm{O}(\mathrm{am})$ due to radiolytic effects, which is in opposition to the Ostwald step rule [Rard, 1989] which predicts changes from an amorphous to a crystalline material.

Owing to difficulties described above, it is quite difficult to interpret some of the published solubility studies. These difficulties include the multiplicity of valence states of plutonium present in its saturated aqueous solutions, the fact that equilibrium is not achieved in many cases even after allowing considerable time for the saturated solutions to equilibrate with the solid phase, the incomplete characterization of solid phases in contact with saturated solutions, the formation of colloids under certain conditions, and the effect of radiolysis on the crystallinity of solid phases. The following discussion is based mainly on the critical analysis of solubility by Puigdomènech and Bruno [Puigdomènech and Bruno, 1991] who compared some of the solubility data graphically. However, a few other experimental studies are also described.

Weigel et al. [Weigel, Katz, and Seaborg, 1986] have summarized solubility data (presumably at "room temperature") for a number of plutonium salts, mostly salts and double salts containing Pu(IV). However, a few salts of $\mathrm{Pu}(\mathrm{VI}), \mathrm{Pu}(\mathrm{V})$, and $\mathrm{Pu}(\mathrm{III})$ were included, as were a few solubility studies for "Pu(OH $)_{3} \cdot \times \mathrm{H}_{2} \mathrm{O}(\mathrm{s}) "$ and $\mathrm{Pu}(\mathrm{OH})_{4} \cdot \mathrm{xH}_{2} \mathrm{O}(\mathrm{s})$." These were not critically assessed 
values, but are useful for qualitative comparisons. By far the most soluble plutonium salts were salts containing $\mathrm{Pu}(\mathrm{VI}): \mathrm{PuO}_{2} \mathrm{Cl}_{2} \cdot 6 \mathrm{H}_{2} \mathrm{O}$ in dilute $\mathrm{HCl}$ and $\mathrm{PuO}_{2}\left(\mathrm{NO}_{3}\right)_{2} \cdot 6 \mathrm{H}_{2} \mathrm{O}$ in $\mathrm{HNO}_{3}$, followed by $\mathrm{Pu}\left(\mathrm{SO}_{4}\right)_{2} \cdot \mathrm{xH}_{2} \mathrm{O}$ in 0.1 molar $\mathrm{H}_{2} \mathrm{SO}_{4}$. The double salt $\left(\mathrm{NH}_{4}\right)_{4} \mathrm{Pu}\left(\mathrm{SO}_{4}\right)_{4} \cdot \times \mathrm{H}_{2} \mathrm{O}$ is also quite soluble [Anderson, 1949]. However, the solubility of $\mathrm{Pu}\left(\mathrm{SO}_{4}\right)_{2} \cdot \mathrm{xH}_{2} \mathrm{O}$ is reduced considerably in the presence of fluoride salts [Deichman and Tananaev, 1962]. Plutonium(IV) hydroxynitrates have also been reported to be very soluble at $\mathrm{pH}<2$ [Schmidt, Andryushin, et al., 1981]. The least soluble plutonium compounds considered by Weigel et al. were " $\mathrm{Pu}(\mathrm{OH})_{4} \cdot \mathrm{HH}_{2} \mathrm{O}(\mathrm{s})$ " and $\mathrm{Pu}(\mathrm{IV})$ peroxides in concentrated acidic aqueous hydrogen peroxide.

A number of studies report solubilities of various oxides, hydroxides, and hydrous oxides of plutonium in the absence of carbonate, phosphate, or other strongly complexing ligands [Davydov, 1967; Moskvin and Zaitseva, 1962; Felmy, Rai, et al., 1989; Kim and Kanellakopulos, 1989; Musante and Porthaulte, 1973; Pérez-Bustamante, 1965; Rai, 1984; Rai and Ryan, 1982; Rai, Serne, and Swanson, 1980] and a few other studies have been cited by Puigdomènech and Bruno [Puigdomènech and Bruno, 1991]. The assessed solubilities of Puigdomènech and Bruno indicate that $\mathrm{PuO}_{2}(\mathrm{OH})_{2}(\mathrm{cr})$ has a minimum solubility of about $10^{-8}$ molar at $\mathrm{pH}$ around 10 to 11 , but becomes more soluble as the $\mathrm{pH}$ decreases, ca. $10^{-2}$ molar at low $\mathrm{pHs}$. The assessed solubilities of $\mathrm{PuO}_{2} \cdot \times \mathrm{H}_{2} \mathrm{O}(\mathrm{am})$ have a minimum of about $10^{-10}$ to $10^{-9}$ molar for $\mathrm{pHs}$ of about 8 to 12 . $\mathrm{Pu}(\mathrm{OH})_{3}(\mathrm{~s})$ has a minimum solubility of $\leq 1 \times 10^{-9}$ molar for $\mathrm{pH} \approx 9$ to 13 , but it increases rapidly at lower $\mathrm{pHs}$, reaching a value of about $1 \times 10^{-4}$ molar at $\mathrm{pH}=7$ [Felmy, Rai, et al., 1989]. Crystalline $\mathrm{PuO}_{2}$ is expected to have lower solubilities than $\mathrm{PuO}_{2} \cdot \mathrm{xH}_{2} \mathrm{O}(\mathrm{am})$, but radiolysis products gradually convert it into the more soluble $\mathrm{PuO}_{2} \cdot \mathrm{xH}_{2} \mathrm{O}(\mathrm{am})$ [Rai and Ryan, 1982].

Numerous studies have been performed of plutonium solubilities in carbonate solutions, e.g., see references [Gel'man, Moskvin, and Zaitseva, 1962; Nitsche, 1987; Nitsche, Roberts, et al., 1994; Pashalidis, Runde, and Kim, 1993; Robuch and Vitorge, 1987; Yamaguchi, Sakamoto, and Ohnuki, 1994] and additional studies cited by Puigdomènech and Bruno [Puigdomènech and Bruno, 1991] and [Clark, Hobart, and Neu, 1995]. Critically assessed stability constants of the plutonium carbonates and hydroxy carbonates have been reported [Clark, Hobart, and Neu, 1995; Kim, 1986; Newton and Sullivan, 1985]. Solubilities of $\mathrm{PuO}_{2}(\mathrm{cr})$ and $\mathrm{PuO}_{2} \cdot \mathrm{xH}_{2} \mathrm{O}(\mathrm{am})$ in solutions containing 
carbonate have a minimum solubility of about $10^{-8}$ molar from about $7.5 \leq$ $\mathrm{pH} \leq 9.6$ but the solubilities increase considerably at higher and lower $\mathrm{pHs}$. The solubility of $\mathrm{Pu}(\mathrm{VI})$ in carbonate solutions reaches a minimum of about $2.5 \times 10^{-5}$ molar for carbonate concentrations of about $10^{-8}$ to $3 \times 10^{-6}$ molar, but is considerably higher at higher and lower carbonate concentrations because of changes in the aqueous complexes and changes in the solid phase. These solid phases include $\mathrm{PuO}_{2} \mathrm{CO}_{3}(\mathrm{~s})$ [Pashalidis, Runde, and Kim, 1993; Robuch and Vitorge, 1987], possibly $\mathrm{NaPuO}_{2} \mathrm{CO}_{3}$ (s) [Nitsche, Roberts, et al., 1994], and $\left(\mathrm{NH}_{4}\right)_{4} \mathrm{PuO}_{2}\left(\mathrm{CO}_{3}\right)_{3}(\mathrm{~s})$ [Gel'man, Moskvin, and Zaitseva, 1962].

Solubilities of $\mathrm{Pu}(\mathrm{IV})$ in phosphoric acid and acidic phosphate solutions [Denotkina and Shevchenko, 1967a, 1967b; Denotkina, Moskvin, and Shevchenko, 1960; King, 1949; Moskvin, 1971a; Puigdomènech and Bruno, 1991] have been reported. The assessment of Puigdomènech and Bruno indicates that $\mathrm{PuPO}_{4} \cdot \mathrm{xH}_{2} \mathrm{O}(\mathrm{s})$ has a minimum solubility of about $10^{-5}$ molar for $\mathrm{pH}>3.5, \mathrm{Pu}\left(\mathrm{HPO}_{4}\right)_{2} \cdot \mathrm{xH}_{2} \mathrm{O}(\mathrm{s})$ has solubilities of about $10^{-4}$ to $10^{-3}$ molar for wide ranges of concentration of added acid, and that $\mathrm{PuO}_{2}\left(\mathrm{HPO}_{4}\right) \cdot 4 \mathrm{H}_{2} \mathrm{O}(\mathrm{s})$ has a solubility of about $2 \times 10^{-5}$ molar in water but which increases to about $10^{-3}$ molar in excess $\mathrm{H}_{3} \mathrm{PO}_{4}(\mathrm{aq})$. Stability constants for the $\mathrm{HPO}_{4}^{2-}$ and $\mathrm{H}_{2} \mathrm{PO}_{4}^{-}$ complexes of plutonium have been tabulated [Andersson, 1989; Lemire and Tremaine, 1980] as have Gibbs energies of formation of these complexes [Lemire and Garisto, 1989].

No solubilities were located for plutonium silicates. However, based on anologies with uranyl silicates [Moll, Geipel., et al., 1996; Nguyen, Silva, et al., 1992; Puidgomènech and Bruno, 1988] we expect $\left(\mathrm{PuO}_{2}\right)_{2} \mathrm{SiO}_{4} \cdot \times \mathrm{H}_{2} \mathrm{O}(\mathrm{s})$ to be comparable in solubility to $\mathrm{PuO}_{2}(\mathrm{OH})_{2}(\mathrm{~s})$.

Examination of the solubility and redox information summarized in the preceding paragraphs indicates that minimum solubilities for plutonium are favored by $\mathrm{pH} \approx 8$ or 9 to 13 , by very low carbonate concentrations, by very low concentrations of phosphate (especially when the solutions are acidic), and by slightly reducing conditions. Oxidizing conditions and acidic $\mathrm{pHs}$ favor increased solubility, as do alkaline conditions when high concentrations. of carbonate are present.

It was suggested in the discussion for neptunium that two of the three conditions needed to lower solubilities could be met by adding materials that compete for carbonate and phosphate from infiltrating groundwater, by forming sparingly soluble carbonate and phosphate precipitates, and which 
increase the alkalinity. A suggested possibility was to add mixtures of gypsum $\left(\mathrm{CaSO}_{4} \cdot 2 \mathrm{H}_{2} \mathrm{O}\right)$ or anhydrite $\left(\mathrm{CaSO}_{4}\right)$ and lime $(\mathrm{CaO})$ to raise the $\mathrm{pH}$ into a favorable range as these materials dissolve, and which would provide sources of calcium ions to precipitate most of the dissolved carbonate/bicarbonate as calcite $\left(\mathrm{CaCO}_{3}\right)$. Precipitation of hydroxy apatite, $\mathrm{Ca}_{10}\left(\mathrm{PO}_{4}\right)_{6}(\mathrm{OH})_{2}$, or calcium phosphate, $\mathrm{Ca}_{3}\left(\mathrm{PO}_{4}\right)_{2}$, would help to sequester the phosphate. Thus the suggested additives would also be beneficial for reducing the solubility of plutonium. Use of $\mathrm{MgO}$ (periclase) may also be satisfactory [Jackson, 1996]. Solubilities of $\mathrm{PuO}_{2} \cdot \times \mathrm{H}_{2} \mathrm{O}(\mathrm{s})$ of about $10^{-10}$ molar have been observed in cement-equilibrated waters [Ewart, House, et al., 1986], which indicates that this system would also be satisfactory.

The solubility data discussed above indicate that $\mathrm{PuO}_{2}(\mathrm{OH})_{2}(\mathrm{cr})$ and other $\mathrm{Pu}(\mathrm{VI})$ compounds should be avoided as the solid phase since they are more soluble than the oxides, hydroxides, and hydrous oxides of $\mathrm{Pu}(\mathrm{IV})$ and $\mathrm{Pu}(\mathrm{III})$. $\mathrm{PuO}_{2}$ (cr) is probably the least soluble of all of these compounds, but available evidence suggests that radiolysis products will convert it to poorly crystalline or amorphous $\mathrm{PuO}_{2}$ (s) or $\mathrm{PuO}_{2} \cdot \times \mathrm{H}_{2} \mathrm{O}(\mathrm{am})$. These other two $\mathrm{Pu}(\mathrm{IV})$ materials have solubilities similar to those of $\mathrm{Pu}(\mathrm{OH})_{3}(\mathrm{~s})$, and any of them should be about equally satisfactory for reducing the solubility of plutonium. Reducing conditions with $\mathrm{Eh}<-0.2 \mathrm{~V}$ should be adequate for maintaining $\mathrm{Pu}(\mathrm{OH})_{3}(\mathrm{~s})$ as the solid phase. Using the $\Gamma / \Gamma_{3}$ redox buffer or certain metal powders, as suggested for neptunium, should be more than adequate to form and preserve $\mathrm{Pu}(\mathrm{OH})_{3}(\mathrm{~s})$. A sparingly soluble salt such as $\mathrm{Cul}$ might make a suitable additive for slow release of iodide. Corrosion of the overpack would also contribute to the desired reducing environment close to the waste canister.

\section{Uranium}

Speciation diagram calculations [Allard, Kipatsi, and Liljezin, 1980; Grenthe, Fuger, et al., 1992; Langmuir, 1978; Lemire and Garisto, 1989; Martinot, 1978] and potential diagrams [Martinot and Fuger, 1985] using available thermodynamic data bases indicate that dissolved species of $U(I I I)$, $\mathrm{U}(\mathrm{IV}), \mathrm{U}(\mathrm{V})$, and $\mathrm{U}(\mathrm{VI})$ can be present in aqueous solutions. However, $\mathrm{U}(\mathrm{III})$ can form only under extremely reducing conditions and at acidic $\mathrm{pHs}$, and its standard reduction potential of $\mathrm{E}^{\circ}=-0.55 \mathrm{~V}$ [Grenthe, Fuger, et al., 1992] indicates that it will readily reduce water. Thus it is absent under 
environmental conditions. The dominant valence state of uranium in water under oxidizing conditions is $\mathrm{U}(\mathrm{VI})$ in the form of the uranyl ion $\mathrm{UO}_{2}^{2+}(\mathrm{aq})$ and its various hydrolyzed forms and complexes. The standard potential for the reduction of $\mathrm{UO}_{2}^{2+}(\mathrm{aq})$ to $\mathrm{U}^{4+}(\mathrm{aq}), \mathrm{E}^{\circ}=0.27 \mathrm{~V}$ [Grenthe, Fuger, et al., 1992] indicates that U(IV) will be important in deoxygenated systems and under reducing conditions. Electrolytic reduction of $\mathrm{UO}_{2}^{2+}(\mathrm{aq})$ yields $\mathrm{UO}_{2}^{+}(\mathrm{aq})$, but U(V) species predominate over U(IV) and U(VI) species only over very narrow conditions of $\mathrm{pH}$ and Eh. Ihus, for most practical purposes, the aqueous chemistry of uranium is dominated by $U(V I)$ and $U(I V)$.

In this section a large number of aqueous studies for uranium compounds and salts are described. The published literature for uranium is so extensive that many more references could have been included. However, many of these have been included in the recent Nuclear Energy Agency (NEA) review of uranium thermodynamics [Grenthe, Fuger, et al., 1992], and solubilities of uranium oxides, hydroxides, and carbonates were reviewed in an SKB report [Puigdomènech and Bruno, 1988; also see Bruno and Puigdomènech, 1989]. Extensive listings of older solubility data can be found in the book by Linke [Linke, W. F., 1965]. These three reviews should be used as sources for references to numerous additional solubility studies. Gibbs energies of formation of various solid compounds, aqueous ions, and complexes of uranium have been reviewed critically [Grenthe, Fuger, et al., 1992; Langmuir, 1978; Lemire and Tremain, 1980]. Langmuir [Langmuir, 1978] discussed the uranium solution solid equilibria relevant to the formation of sedimentary ore deposits.

Many of the uranyl salts with common inorganic anions are extremely soluble. For example, the solubility of $\mathrm{UO}_{2}\left(\mathrm{NO}_{3}\right)_{2} \cdot 6 \mathrm{H}_{2} \mathrm{O}(\mathrm{cr})$ is 3.21 molal at $298 \mathrm{~K}$ and 6.17 molal at $328 \mathrm{~K}$ [Cohen-Adad, Lorimer, et al., 1995]. The solubility of $\mathrm{UO}_{2} \mathrm{SO}_{4} \cdot 3 \mathrm{H}_{2} \mathrm{O}(\mathrm{s})$ is about 4 molal at $298 \mathrm{~K}$ and about 7 molal at $425 \mathrm{~K}$ [Secoy, 1948]. Above about $594 \mathrm{~K}$ two separate liquid phases are observed [Secoy, 1950]. The uranyl halides are also quite soluble, especially $\mathrm{UO}_{2} \mathrm{~F}_{2} \cdot 2 \mathrm{H}_{2} \mathrm{O}(\mathrm{s})$ [Linke, 1965], as is $\mathrm{UO}_{2}\left(\mathrm{ClO}_{4}\right)_{2} \cdot \mathrm{xH}_{2} \mathrm{O}(\mathrm{s})$ [Goldberg, 1979]. .

Uranium(VI) can form a variety of anhydrous and hydrated oxides. The oxide $\mathrm{UO}_{3}$ (s) can exist in at least five different crystalline forms, denoted as $\alpha$, $\beta, \gamma, \delta$, and $\varepsilon$, along with an amorphous material. The hydrated oxides include $\mathrm{UO}_{3} \cdot 2 \mathrm{H}_{2} \mathrm{O}(\mathrm{cr})$, two or three forms of $\mathrm{UO}_{3} \cdot \mathrm{H}_{2} \mathrm{O}(\mathrm{cr})$, some substoichiometric hydrates of the type $\mathrm{UO}_{3} \cdot \mathrm{xH}_{2} \mathrm{O}(\mathrm{s})$ where $\mathrm{x}=0.8$ or 0.9 , and a lower hydrate 
sometimes claimed to be $\mathrm{UO}_{3} \cdot 0.5 \mathrm{H}_{2} \mathrm{O}(\mathrm{s})$. This $\beta$-UOO $3 \cdot \mathrm{H}_{2} \mathrm{O}(\mathrm{cr})$ is also frequently written as $\beta-\mathrm{UO}_{2}(\mathrm{OH})_{2}(\mathrm{cr})$. See the discussions in the NEA thermodynamic review [Grenthe, Fuger, et al., 1992] and the article by O'Hare et al. [O'Hare, Lewis, and Nguyen, 1988]. The mineral schoepite, $\mathrm{UO}_{2}(\mathrm{OH})_{2} \cdot \mathrm{H}_{2} \mathrm{O}(\mathrm{cr})$ or $\mathrm{UO}_{3} \cdot 2 \mathrm{H}_{2} \mathrm{O}(\mathrm{cr})$, widely known in geological situations, is believed to form during the weathering of uraninite $\left(\mathrm{UO}_{2}\right)$ under oxidizing conditions. It has also been observed to form in long-term leaching studies of spent nuclear fuel under oxidizing conditions [Bruno and Sandino, 1989]. The most important of these oxides, hydroxides, and hydrous oxides from the viewpoint of disposal of nuclear waste is schoepite, and it is the only one that will be discussed in more detail. However the NEA review [Grenthe, Fuger, et al., 1992] gives a detailed discussion and critical review of the available thermodynamic information, and their critically assessed values could be used to predict the solubilities of the other phases.

Numerous studies have been reported of the solubility of schoepite in waters of various compositions and pHs [Babko and Kodenskaya, 1960; Brusilovskii, 1958; Bruno and Sandino, 1989; Gayer and Leider, 1955; Gryzin and Koryttsev, 1967; Kim, Choi, et al., 1994; Krupka, Rai, et al., 1985] and a few other studies were cited by Puigdomènech and Bruno [Puigdomènech and Bruno, 1988]. Most of these data are for the crystalline material, and the majority of these studies are in reasonable agreement. The analysis by Puigdomènech and Bruno indicates that the solubility at $298 \mathrm{~K}$ is at a minimum from $\mathrm{pH}=8$ to 9 , at about $2.5 \times 10^{-6}$ to $6 \times 10^{-5}$ molar. However, it increases rapidly with $\mathrm{pH}$ at both higher and lower $\mathrm{pHs}$, and solubilities of about $10^{-1}$ molar are observed by $\mathrm{pH}=4$. Bruno and Sandino [Bruno and Sandino, 1989] found that the solubility of amorphous schoepite was about 10 to 30 times more soluble than microcrystalline material for the same $\mathrm{pH}$ range.

Formation constants for the uranyl carbonates and mixed hydroxycarbonates are fairly large [Clarke, Hobart, and Neu, 1995; Grenthe, Fuger, et al., 1992; Newton and Sullivan, 1985] and indicate that the presence of carbonate will considerably enhance the solubility of schoepite.

The solubility of sodium uranate $\mathrm{Na}_{2} \mathrm{U}_{2} \mathrm{O}_{7}(\mathrm{~s})$ was reported to be $2.05 \times 10^{-5}$ molar in cement-equilibrated water saturated with $\mathrm{NaCl}$ [Marx and Keiling, 1989]; the $\mathrm{pH}$ of this solution was presumably about 11 . Solubilities of a uranium(VI) sodium uranate, presumably also $\mathrm{Na}_{2} \mathrm{U}_{2} \mathrm{O}_{7}(\mathrm{~s})$, in cement- 
equilibrated water were reported graphically for $\mathrm{pH} \approx 3.5$ to 13 [Brownsword, Buchan, et al., 1989]. The solubility had a rather broad minimum of from 10-6 to $10^{-5}$ molar for $\mathrm{pH}=6$ to 13 , but showed a rapid increase in solubility at lower $\mathrm{pHs}$.

A number of solubility studies have been reported for the uranyl carbonate rutherfordinde, $\mathrm{UO}_{2} \mathrm{CO}_{3}(\mathrm{cr})$. See, for example, the studies [Grenthe, Ferri, et al., 1984; Sergeyeva, Nikitin, et al., 1972] and also other reports referenced by Puigdomènech and Bruno [Puigdomènech and Bruno, 1988]. It has been reported that to synthesize this material from aqueous solutions requires a partial pressure of $\mathrm{CO}_{2}(\mathrm{~g})$ that is $>3 \times 10^{-4}$ atm [Grenthe, Ferri, et al., 1984; Sergeyeva, Nikitin, et al., 1972], whereas Babko and Kodenskaya claim that a molar concentration of dissolved $\mathrm{CO}_{2}$ of $>0.6$ molar is required [Babko and Kodenskaya, 1960]. The solubility minimum for uranyl carbonate of about $2 \times$ $10^{-5}$ to $10^{-4}$ molar occurs around $\mathrm{pH} \approx 5$, with rapid increases in solubility at higher and lower $\mathrm{pHs}$. The existence of numerous uranyl carbonate, hydroxycarbonate, and possibly a hydroxybicarbonate complex in the solution phases gives rise to this strong variation of solubility with $\mathrm{pH}$ [Clark, Hobart, and Neu, 1995; Grenthe, Fuger, et al., 1992; Lemire and Garisto, 1989; Lemire and Tremaine, 1980; Newton and Sullivan, 1985]. Its solubility varies little with temperature [Puigdomènech and Bruno, 1988; Sergeyeva, Nikitin, et al., 1972].

Solubilities have been reported for the uranyl phosphates $\left(\mathrm{UO}_{2}\right)_{3}\left(\mathrm{PO}_{4}\right)_{2} \cdot 6 \mathrm{H}_{2} \mathrm{O}(\mathrm{s}), \mathrm{UO}_{2}\left(\mathrm{HPO}_{4}\right) \cdot 4 \mathrm{H}_{2} \mathrm{O}(\mathrm{s}), \mathrm{UO}_{2}\left(\mathrm{H}_{2} \mathrm{PO}_{4}\right)_{2} \cdot 3 \mathrm{H}_{2} \mathrm{O}(\mathrm{s})$, and $\mathrm{UO}_{2}\left(\mathrm{HPO}_{4}\right)(\mathrm{s})$ and their mixtures with $\mathrm{H}_{3} \mathrm{PO}_{4}$ [Karpov, 1961; Marković and Pavković, 1983; Moskvin, Shelyakina, and Perminov, 1967; Schreyer and Baes, 1954; Veselý, Pekárek, and Abbrent, 1965]. The reported solubility of $\mathrm{UO}_{2}\left(\mathrm{HPO}_{4}\right) \cdot 4 \mathrm{H}_{2} \mathrm{O}(\mathrm{s})$ in water at $298.15 \mathrm{~K}$ is $6 \times 10^{-5}$ molar [Moskvin, Shelyakina, and Perminov, 1967], although Schreyer and Baes reported that this solid phase only formed when the total phosphate concentration in the solution was between 0.014 and 6.1 molar [Schreyer and Baes, 1954]. At higher phosphate concentrations $\mathrm{UO}_{2}\left(\mathrm{H}_{2} \mathrm{PO}_{4}\right)_{2} \cdot 3 \mathrm{H}_{2} \mathrm{O}$ (s) becomes the precipitating phase. These phase studies were done in solutions of $\mathrm{H}_{3} \mathrm{PO}_{4}$, so high acidities were also involved. Concentrations of uranyl as high as 0.2 molar in solutions could be obtained at high concentrations of $\mathrm{H}_{3} \mathrm{PO}_{4}$. Evaluated solubility products are $8 \times 10^{-13}$ for $\mathrm{UO}_{2}\left(\mathrm{HPO}_{4}\right)(\mathrm{s}), 2 \times 10^{-24}$ for "( $\left(\mathrm{UO}_{2}\right)_{2}\left(\mathrm{HPO}_{4}\right)_{2}(\mathrm{~s})$," and $1 \times 10^{-49}$ for $\left(\mathrm{UO}_{2}\right)_{3}\left(\mathrm{PO}_{4}\right)_{2}(\mathrm{~s})$ [Anderson, 1989]. The 
second of these formulas is equivalent to $\mathrm{UO}_{2}\left(\mathrm{HPO}_{4}\right)(\mathrm{s})$. Presumably, these solubility products actually refer to the hydrated solids. The NEA review of uranium thermodynamics [Grenthe, Fuger, et al., 1992] reports a value of the thermodynamic solubility product of $5 \times 10^{-54}$ for $\left(\mathrm{UO}_{2}\right)_{3}\left(\mathrm{PO}_{4}\right)_{2} \cdot 4 \mathrm{H}_{2} \mathrm{O}$ (cr) from an unpublished disscrtation. They attributed this smaller value to use of material with greater crystallinity than in the earlier studies, although differences in the number of waters of hydration may also have been present. Numerous complexes of the uranyl ion with $\mathrm{HPO}_{4}^{2-}, \mathrm{H}_{2} \mathrm{PO}_{4}^{-}$, and $\mathrm{H}_{3} \mathrm{PO}_{4}$ have been reported [Grenthe, Fuger, et al., 1992; Lemire and Garisto, 1989], and their formation is responsible for the rapid increase in solubility of the phosphates with increasing acidity. Evidence for additional hydrates of the uranyl phosphates are summarized in the NEA review [Grenthe, Fuger, et al., 1992].

Solubilitics have also been reported for various alkali metal and ammonium uranyl phosphates: $\mathrm{LiUO}_{2} \mathrm{PO}_{4} \cdot \times \mathrm{H}_{2} \mathrm{O}(\mathrm{s}), \mathrm{NaUO}_{2} \mathrm{PO}_{4} \cdot \times \mathrm{H}_{2} \mathrm{O}(\mathrm{s})$, $\mathrm{KUO}_{2} \mathrm{PO}_{4} \cdot \times \mathrm{H}_{2} \mathrm{O}(\mathrm{s}), \mathrm{RbUO}_{2} \mathrm{PO}_{4} \cdot \mathrm{xH}_{2} \mathrm{O}(\mathrm{s}), \mathrm{CsUO}_{2} \mathrm{PO}_{4} \cdot x \mathrm{H}_{2} \mathrm{O}(\mathrm{s})$, and $\mathrm{NH}_{4} \mathrm{UO}_{2} \mathrm{PO}_{4} \cdot \times \mathrm{H}_{2} \mathrm{O}(\mathrm{s})$ [Chukhlantsev and Stepanov, 1956; Moskvin, Shelyakina, and Perminov, 1967; Murav'eva, Zaborenko, et al., 1964; Veselý, Pekárek, and Abbrent, 1965]. These solid phases form from solutions of alkali metal or ammonium salts in the presence of phosphoric acid. Evaluated solubility products at $293 \mathrm{~K}$ [Veselý, Pekárek, and Abbrent, 1965] are: $6 \times 10^{-25}$ for $\mathrm{NaUO}_{2} \mathrm{PO}_{4} \cdot \times \mathrm{H}_{2} \mathrm{O}(\mathrm{s}), 3 \times 10^{-26}$ for $\mathrm{KUO}_{2} \mathrm{PO}_{4} \cdot \times \mathrm{H}_{2} \mathrm{O}(\mathrm{s}), 2 \times 10^{-26}$ for $\mathrm{RbUO}_{2} \mathrm{PO}_{4} \cdot \times \mathrm{H}_{2} \mathrm{O}(\mathrm{s}), 4 \times 10^{-26}$ for $\mathrm{CsUO}_{2} \mathrm{PO}_{4} \cdot \mathrm{xH}_{2} \mathrm{O}(\mathrm{s})$, and $6 \times 10^{-27}$ for $\mathrm{NH}_{4} \mathrm{UO}_{2} \mathrm{PO}_{4} \cdot x \mathrm{H}_{2} \mathrm{O}(\mathrm{s})$. These double salts are significantly more soluble than $\left(\mathrm{UO}_{2}\right)_{3}\left(\mathrm{PO}_{4}\right)_{2} \cdot 6 \mathrm{H}_{2} \mathrm{O}(\mathrm{s})$.

As noted earlier, $\mathrm{UO}_{2} \mathrm{SO}_{4} \cdot 3 \mathrm{H}_{2} \mathrm{O}(\mathrm{s})$ is very soluble in water. However, various divalent metal mixed hydroxysulfates (zippeites) are known with the general formula $\mathrm{M}(\mathrm{II})_{2}\left(\mathrm{UO}_{2}\right)_{6}\left(\mathrm{SO}_{4}\right)_{3}(\mathrm{OH})_{10} \cdot \mathrm{xH}_{2} \mathrm{O}(\mathrm{s})$, and which are much less soluble [Haacke and Williams, 1979]. Reported solubility products at $298 \mathrm{~K}$ are: $8 \times 10^{-147}$ for $\mathrm{Mg}_{2}\left(\mathrm{UO}_{2}\right)_{6}\left(\mathrm{SO}_{4}\right)_{3}(\mathrm{OH})_{10} \times \mathrm{H}_{2} \mathrm{O}(\mathrm{s}), 1 \times 10^{-146}$ for $\mathrm{Co}_{2}\left(\mathrm{UO}_{2}\right)_{6}\left(\mathrm{SO}_{4}\right)_{3}(\mathrm{OH})_{10} \times \mathrm{xH}_{2} \mathrm{O}(\mathrm{s}), 3 \times 10^{-146}$ for $\mathrm{Ni}_{2}\left(\mathrm{UO}_{2}\right)_{6}\left(\mathrm{SO}_{4}\right)_{3}(\mathrm{OH})_{10} \cdot \times \mathrm{H}_{2} \mathrm{O}(\mathrm{s})$, and $1 \times 10^{-153}$ for $\mathrm{Zn}_{2}\left(\mathrm{UO}_{2}\right)_{6}\left(\mathrm{SO}_{4}\right)_{3}(\mathrm{OH})_{10} \times \mathrm{H}_{2} \mathrm{O}(\mathrm{s})$. These extremely small values occur because they represent complete dissociation to form $\mathrm{M}^{2+}, \mathrm{UO}_{2}^{2+}$, $\mathrm{SO}_{4}^{2-}$, and $\mathrm{OH}^{-}$. The actual total concentration of $\mathrm{UO}_{2}^{2+}$ is about $\approx 10^{-5}$ molar in these solutions at $\mathrm{pH} \approx 5$. These solubility products are not very certain since the solubilities were measured at a single $\mathrm{pH}$. 
The uranium silicate mineral soddyite, $\left(\mathrm{UO}_{2}\right)_{2} \mathrm{SiO}_{4} \cdot 2 \mathrm{H}_{2} \mathrm{O}(\mathrm{s})$, is well known and is a possible solubility limiting phase under oxidizing conditions for uranium solutions containing dissolved silica [Moll, Geipel, et al., 1996; Nguyen, Silva, et al., 1992]. Its solubilities have been determined at $303 \mathrm{~K}$ [Nguyen, Silva, et al., 1992] and $298 \mathrm{~K}$ [Moll, Geipel, et al., 1996]. In both studies it required about 60 to 100 days to reach saturation equilibrium (or a steady state). A minimum solubility of about $10^{-5}$ molar is observed at $\mathrm{pH} \approx 6$, but higher solubilities are observed both at lower and higher $\mathrm{pH}$. Solubilities greater than $10^{-2}$ molar occur at $\mathrm{pH}=3$. Nguyen et al. [Nguyen, Silva, et al., 1992] also determined solubilities of synthetic uranophane, $\mathrm{Ca}\left(\mathrm{H}_{3} \mathrm{O}\right)_{2}\left(\mathrm{UO}_{2}\right)\left(\mathrm{SiO}_{4}\right)_{2} \cdot 3 \mathrm{H}_{2} \mathrm{O}(\mathrm{cr})$, synthetic sodium boltwoodite, $\mathrm{Na}\left(\mathrm{H}_{3} \mathrm{O}\right)\left(\mathrm{UO}_{2}\right) \mathrm{SiO}_{4} \cdot \mathrm{H}_{2} \mathrm{O}(\mathrm{cr})$, and synthetic sodium weeksite, $\mathrm{Na}_{2}\left(\mathrm{UO}_{2}\right)_{2}\left(\mathrm{Si}_{2} \mathrm{O}_{5}\right)_{3} \cdot 7 \mathrm{H}_{2} \mathrm{O}(\mathrm{cr})$. Lengthy equilibrations were also required for these systems. The solubility of these three uranyl silicates were slightly lower than that of soddyite, but no detailed comparison is possible since the solubility experiments were performed at a single $\mathrm{pH}$.

Potential-pH diagrams using the critically assessed NEA thermodynamic data base [Grenthe, Fuger, et al., 1992] indicates that in the uranium/oxygen/water phase system at room temperature, schoepite $\left\{\mathrm{UO}_{2}(\mathrm{OH})_{2} \cdot \mathrm{H}_{2} \mathrm{O}(\mathrm{cr})\right.$ or $\left.\mathrm{UO}_{3} \cdot 2 \mathrm{H}_{2} \mathrm{O}(\mathrm{cr})\right\}$ should be the solubility-limiting phase under more oxidizing conditions. However, as the solution becomes less oxidizing the solubility-limiting phase should switch to $\mathrm{U}_{3} \mathrm{O}_{8}(\mathrm{cr})$ \{equivalent to $\left.\mathrm{UO}_{2.6667}(\mathrm{cr})\right\}$, then to $\beta-\mathrm{U}_{3} \mathrm{O}_{7}(\mathrm{cr})$ \{equivalent to $\left.\mathrm{UO}_{2.3333}(\mathrm{cr})\right\}$, to $\beta-\mathrm{U}_{4} \mathrm{O}_{9}(\mathrm{cr})$ \{equivalent to $\mathrm{UO}_{2.25}(\mathrm{cr})$ \}, and finally to uraninite $\mathrm{UO}_{2}$ (cr).

This predicted precipitation series is based on critically assessed calorimetric data in most cases, because detailed solubility studies are available only for the two homovalent end members schoepite and uraninite. There are no obviously reliable solubility data for the mixed-valence uranium oxides according to the NEA review [Grenthe, Fuger, et al., 1992]. Ollila et al. [Ollila, Olin, and Lipponen, 1996] studied the dissolution behavior of polycrystalline $\mathrm{UO}_{2}$ pellets in distilled water and in several synthetic groundwaters containing bicarbonate, with all dissolution experiments performed in nitrogen atmospheres. The fraction of dissolved uranium present as U(VI) varied from 91.4 to $99.0 \%$ in their experiments. They measured solubilities at $\mathrm{pH}=7.0$ and at 8.9-9.1 that were essentially identical to those predicted for $\beta$ $\mathrm{U}_{4} \mathrm{O}_{9}(\mathrm{cr})$ using the NEA data base with $\mathrm{Eh}=-0.3 \mathrm{~V}$. They suggested that the 
surface layer of their $\mathrm{UO}_{2}(\mathrm{cr})$ could have been more highly oxidized due to radiolysis. However, the value of $\mathrm{Eh}=-0.3 \mathrm{~V}$ used in their modeling calculations was assumed rather than measured (their measured values of Eh ranged between +0.15 and $0.18 \mathrm{~V}$ ), and the composition of the solid phase was not analyzed after the solubility experiments were performed. Thus the actually solubility-limiting phase in these experiments is unknown.

It is far from certain that all of these mixed-valence oxides can form by precipitation from aqueous solutions, or by aging of the initial precipitates, or by changing the Eh value of an aqueous solution with which they are in contact. However, mixed valence oxides of uranium do occur as natural minerals, e.g., the mineral ianthinite $\mathrm{UO}_{2.833} \cdot 1.76 \mathrm{H}_{2} \mathrm{O}(\mathrm{s})$ [Grenthe, Fuger, et al., 1992].

The solubility of amorphous or precipitated $\mathrm{UO}_{2}$ has been reported in numerous studies [Bruno, Casas, et al., 1987; Bruno, Ferri, et al., 1986; Galkin and Stepanov, 1960; Gayer and Leider, 1957; Rai, Felmy, and Ryan, 1990; Ryan and Rai, 1983]. This material has been described in the various studies as $\mathrm{UO}_{2}(\mathrm{am}), \mathrm{UO}_{2} \cdot \mathrm{xH}_{2} \mathrm{O}(\mathrm{s}), \mathrm{U}(\mathrm{OH})_{4}(\mathrm{~s})$, etc. For the present discussion we will denote this material as $\mathrm{UO}_{2} \cdot \mathrm{xH}_{2} \mathrm{O}(\mathrm{s})$, although, depending on the precipitation conditions and aging of the solid, its composition could vary from truly amorphous to microcrystalline material and the degree of hydration may vary.

Solubilities reported in three of these studies [Bruno, Casas, et al., 1987; Gayer and Leider, 1957; Galkin and Stepanov, 1960] are fairly consistent with each other [Puigdomènech and Bruno, 1988], and show a minimum solubility of about $3 \times 10^{-5}$ molar between pHs of about 6 to 13 . In contrast, the solubilities measured by the group at PNL [Rai, Felmy, and Ryan, 1990; Ryan and Rai, 1983] have considerably lower solubilities, about $10^{-8}$ to $10^{-7}$ molar for pHs from 6 to 14. In two of these studies [Gayer and Leider, 1957; Galkin and Stepanov, 1960] no attempt was made to control the Eh of the solution, whereas Bruno et al. [Bruno, Casas, et al., 1987] reduced the U(VI) in their solution to $\mathrm{U}(\mathrm{IV})$ by using hydrogen gas, but then replaced the $\mathrm{H}_{2}$ with $\mathrm{N}_{2}$ for the solubility experiments. Ryan and Rai [Ryan and Rai, 1983] used $\mathrm{Na}_{2} \mathrm{~S}_{2} \mathrm{O}_{4}$ (aq) or zinc metal to provide reducing environments in the solubility experiments, whereas Rai et al. [Rai, Felmy, and Ryan, 1990] used iron powder or $\mathrm{Eu}^{2+}(\mathrm{aq})$ as reducing agents. Bruno et al. [Bruno, Casas, et al., 1987] attributed this solubility difference to possibly a greater degree of crystallinity 
in the PNL study [Ryan and Rai, 1983]. Rai et al. [Rai, Felmy, and Ryan, 1990], however, reported $X$-ray diffraction patterns that were very similar to those reported by Bruno et al., so crystallinity differences can not account for the different solubilities. Rai et al. noted that solubilities of $\mathrm{UO}_{2} \cdot \mathrm{xH}_{2} \mathrm{O}(\mathrm{s})$ reported in the other three studies [Bruno, Casas, et al., 1987; Gayer and Leider, 1957; Galkin and Stepanov, 1960] were essentially identical to those of $\mathrm{UO}_{2}(\mathrm{OH})_{2} \cdot \mathrm{H}_{2} \mathrm{O}(\mathrm{cr})$ or $\mathrm{UO}_{3} \cdot 2 \mathrm{H}_{2} \mathrm{O}(\mathrm{cr})$, and thus they attributed the solubility differences to partial oxidation of U(IV) to U(VI). Furthermore, Tremaine et al. [Tremaine, Chen, et al., 1981] found that $\mathrm{UO}_{2}(\mathrm{cr})$ in contact with an aqueous solution at $\mathrm{pH}=12.5$ had slightly more than half of the surface layer oxidized to U(VI) at $298 \mathrm{~K}$ even though the solutions had been purged with $\mathrm{H}_{2}$. Partial oxidation of the surface of $\mathrm{UO}_{2}$ in the other studies [Bruno, Casas, et al., 1987; Gayer and Leider, 1957; Galkin and Stepanov, 1960] seems to be a plausible explanation, and we tentatively accept the results from the PNL studies [Rai, Felmy, and Ryan, 1990; Ryan and Rai, 1983].

Solubilities have also been reported for uraninite, $\mathrm{UO}_{2}$ (cr), in this case from 298 to 873 K [Ollila, Olin, and Lipponen, 1996; Parks and Pohl, 1988; Red'kin, Ivanov, and Omel'yanenko, 1988; Tremaine, Chen., et al., 1981]. The solubilities of Ollila et al. appear to be high, and they suggested that surface oxidation may have occurred on their $\mathrm{UO}_{2}(\mathrm{cr})$. Tremaine et al. did report surface oxidation of their $\mathrm{UO}_{2}(\mathrm{cr})$, and thus their solubilities are also likely to be high by about a factor of about $10^{2}$. The results of Parks and Pohl are probably more reliable, and their solubilities of $\mathrm{UO}_{2}(\mathrm{cr})$ in water only vary from $10^{-9}$ to $10^{-10}$ molar from 373 to $473 \mathrm{~K}$ for $\mathrm{pHs}$ of 2 or 3 to 10 . Their results suggest that a solubility of $10^{-9}$ to $10^{-10}$ molar should be about right for the solubility or uraninite in water at $298.15 \mathrm{~K}$ under reducing conditions.

Stability constants have been reported for the tetra and penta carbonato complexes of U(IV) [Clarke, Hobart, and Neu, 1995; Grenthe, Fuger, et al., 1992; Newton and Sullivan, 1985]. Since these complexes are fairly strong, the presence of carbonate in the aqueous phase will increase the solubility of $\mathrm{UO}_{2} \cdot \mathrm{xH}_{2} \mathrm{O}(\mathrm{s})$ and $\mathrm{UO}_{2}(\mathrm{cr})$ significantly.

The uranium(IV) phosphate $\mathrm{U}\left(\mathrm{HPO}_{4}\right)_{2} \cdot 6 \mathrm{H}_{2} \mathrm{O}(\mathrm{s})$ has been reported [Schreyer, 1955] to form when the total concentration of phosphate was between 1.5 and 9.8 molar. Solubilities were determined in solutions of $\mathrm{H}_{3} \mathrm{PO}_{4}$ but results were only presented graphically. An attempt to determine its solubility in water apparently yielded a partially hydrolyzed product of 
uncertain composition. Grenthe et al. [Grenthe, Fuger, et al., 1992] cited a solubility product (corrected to infinite dilution by them) of $3 \times 10^{-31}$ for $\mathrm{U}\left(\mathrm{HPO}_{4}\right)_{2} \cdot 4 \mathrm{H}_{2} \mathrm{O}(\mathrm{s})$, but without making any corrections for phosphate or hydroxyphosphate complexes owing to a lack of reliable experimental values. Thus this solubility product is highly questionable.

Merkusheva et al. [Merkusheva, Skorik, et al., 1967] studied the solubility of $\mathrm{U}\left(\mathrm{P}_{2} \mathrm{O}_{7}\right) \cdot 20 \mathrm{H}_{2} \mathrm{O}(\mathrm{s})$ at $298 \mathrm{~K}$ in dilute $\mathrm{HClO}_{4}$ at an ionic strength of 0.1 molar. The solubility varied from $3.2 \times 10^{-6}$ molar at $\mathrm{pH}=1.00$ to $1.2 \times 10^{-6}$ molar at $\mathrm{pH}=2.68$. As noted by Grenthe et al. [Grenthe, Fuger, et al., 1992] the solubility product reported by Merkusheva is questionable because of an inadequate knowledge of the aqueous speciation under their experimental conditions.

Several studies report the solubilities of $\mathrm{U}\left(\mathrm{SO}_{4}\right)_{2} \cdot 8 \mathrm{H}_{2} \mathrm{O}(\mathrm{s})$ and $\mathrm{U}\left(\mathrm{SO}_{4}\right)_{2} \cdot 4 \mathrm{H}_{2} \mathrm{O}(\mathrm{s})$ and these solubilities are tabulated by Linke [Linke, 1965]. Solubilities of these salts in water are probably not meaningful owing to gradual "clouding" of the solutions and precipitation of hydrolyzed solids. The reported solubility of $\mathrm{U}\left(\mathrm{SO}_{4}\right)_{2} \cdot 8 \mathrm{H}_{2} \mathrm{O}(\mathrm{s})$ at $298 \mathrm{~K}$ in $0.05 \mathrm{molar}_{2} \mathrm{H}_{2} \mathrm{SO}_{4}$ is about 0.29 molal. Stepanov and Galkin [Stepanov and Galkin, 1962] studied the $\mathrm{pH}$ conditions for precipitation as a function of the concentration of $\mathrm{U}\left(\mathrm{SO}_{4}\right)_{2}(\mathrm{aq})$. From that information they deduced that the basic sulfate formed was $\mathrm{U}(\mathrm{OH})_{2}\left(\mathrm{SO}_{4}\right)(\mathrm{s})$ and that its solubility product (presumably at room temperature) was $7 \times 10^{-32}$. Given that their solubilities refer to fresh precipitates, they are probably much greater that the corresponding equilibrium solubilities.

Examination of the solubility and redox information summarized in the preceding paragraphs indicates that minimum solubilities for uranium are favored by $\mathrm{pH} \approx 6$ to 12 or 13 , by very low carbonate concentrations, by very low concentrations of phosphate (especially when the solutions are acidic), and by very reducing conditions. Oxidizing conditions and acidic $\mathrm{pHs}$ favor increase solubility, as do alkaline conditions when high concentrations of carbonate are present.

It was suggested in the discussion for neptunium and plutonium that two of the three conditions needed to lower solubilities could be met by adding materials that remove carbonate and phosphate from infiltrating groundwater, by forming sparingly soluble precipitates, and which increase the alkalinity. A suggested possibility was to add mixtures of gypsum 
$\left(\mathrm{CaSO}_{4} \cdot 2 \mathrm{H}_{2} \mathrm{O}\right)$ or anhydrite $\left(\mathrm{CaSO}_{4}\right)$ and lime $(\mathrm{CaO})$ to raise the $\mathrm{pH}$ into a favorable range as these materials dissolve, and which would provide sources of calcium ions to precipitate most of the dissolved carbonate/bicarbonate as calcite $\left(\mathrm{CaCO}_{3}\right)$ and dissolved phosphate as hydroxy apatite, $\mathrm{Ca}_{10}\left(\mathrm{PO}_{4}\right)_{6}(\mathrm{OH})_{2}$, or calcium phosphate, $\mathrm{Ca}_{3}\left(\mathrm{PO}_{4}\right)_{2}$. These same additives would also be beneficial for reducing the solubility of uranium. Use of $\mathrm{MgO}$ (periclase) [Jackson, 1996] or cement-equilibrated waters may also be satisfactory.

The solubility data discussed above indicate that schoepite and other U(VI) compounds should be avoided as the solid phase since they are considerably more soluble than the oxides, hydroxides, and hydrous oxides of U(IV). $\mathrm{UO}_{2}(\mathrm{cr})$ is probably the least soluble of all of these compounds, but $\mathrm{UO}_{2} \cdot \mathrm{xH}_{2} \mathrm{O}(\mathrm{s})$ also appears to have very low solubilities. However, the surface layer of $\mathrm{UO}_{2}(\mathrm{cr})$ and $\mathrm{UO}_{2} \times \mathrm{xH}_{2} \mathrm{O}(\mathrm{s})$ is extremely sensitive to the presence of oxygen and even a brief exposure can oxidize the surface partially to U(VI). These more highly oxidized surface layers appear to have solubilities greater by factors of $10^{2}$ to $10^{3}$ than those of the corresponding unoxidized materials. Highly reducing conditions with $\mathrm{Eh}<-0.3 \mathrm{~V}$ are essential for maintaining $\mathrm{UO}_{2}$ ( $\mathrm{cr}$ ) or $\mathrm{UO}_{2} \cdot \mathrm{xH}_{2} \mathrm{O}(\mathrm{s})$ as the solid phase. Using the $\Gamma / \Gamma_{3}$ redox buffer or certain metal powders, as suggested for neptunium and plutonium, should be adequate. A sparingly soluble salt such as CuI might make a suitable additive for slow release of iodide. Corrosion of the overpack would also contribute to the desired reducing environment close to the waste canister.

\section{Additional Comments About the Literature Search}

There is a recent review of the aqueous solubilities of the actinide nitrates: IUPAC Solubility Data Series, Vol. 55, Actinide Nitrates, S. Siekierski and S. L. Phillips editors, Oxford University Press, Oxford, 1994. The subscription to the IUPAC Solubility Data Series in the library at Lawrence Livermore National Laboratory is complete through volume 53 but was then terminated. There were also several articles in published conference proceedings or books that were sought and which were once available in the library at LLNL, but which are no longer available since they were removed from the "stacks" to make space for newer reports. Some of the journal subscriptions (e.g., the Soviet Journal of Radiochemistry) did not extend far enough back in time to include issues reporting some of the early solubility studies. 
In spite of this difficulty, a considerable number of reports on the aqueous solubilities of these three actinides were acquired, including the majority of those studies that were published as journal articles, and including the majority of the recent reports. We believe that solubility values contained in those reports that were unobtainable on short notice will merely confirm the conclusions contained in the present report.

\section{Acknowledgment}

J. A. R. thanks Dr. Kastriot Spahiu for supplying copies of several SKB documents and Dr. Brian E. Viani for helpful suggestions and comments. 


\section{Literature Cited}

Allard, B., Kipatsi, H., and Liljenzin, J. O. (1980) Expected species of uranium, neptunium and plutonium in neutral aqueous solutions. J. Inorg. Nucl. Chem. 42, 1015-1027.

Anderson, H. H. (1949) Alkali plutonium(IV) sulfates. In: The Transuranium Elements: Research Papers, G. T. Seaborg, J. J. Katz, and W. M. Manning editors, McGraw-Hill, New York, pp. 724-728.

Andersson, K. (1989) Possible complex formation of actinides with organic matter and phosphate in deep groundwaters, speciation calculations and data evaluation. In: Scientific Basis for Nuclear Waste Management XII, Materials Research Society Symposium Proceedings Vol. 127, pp. 693-700.

Babko, A. K., and Kodenskaya, V. S. (1960) Equilibria in solutions of uranyl carbonate complexes. Russ. J. Inorg. Chem. 5, 1241-1244.

Brownsword, M., Buchan, A. B., Ewart, F. T., McCrohon, R., Ormerod, G. J., Smith-Briggs, J. L., and Thomason, H. P. (1990) The solubility and sorption of uranium (VI) in a cementitious repository. In: Scientific Basis for Nuclear Waste Management XIII, Materials Research Society Symposium Proceedings Vol. 176, pp. 577-582.

Bruno, J., Casas, I., Lagerman, B., and Munoz, M. (1987) The determination of the solubility of amorphous $\mathrm{UO}_{2}(\mathrm{~s})$ and the mononuclear hydrolysis constants of uranium(IV) at $25^{\circ} \mathrm{C}$. In: Scientific Basis for Nuclear Waste Management X, Materials Research Society Symposium Proceedings Vol. 84, pp. 153-160.

Bruno, J., Ferri, D., Grenthe, I., and Salvatore, F. (1986) Studies on metal carbonate equilibria. 13. On the solubility of uranium(IV) dioxide, $\mathrm{UO}_{2}(\mathrm{~s})$. Acta Chem. Scand. 40, 428-434.

Bruno, J., and Puigdomenech, I. (1989) Validation of the SKBU1 uranium thermodynamic data base for its use in geochemical calculations with EQ3/6. In: Scientific Basis for Nuclear Waste Management XII, Materials Research Society Symposium Proceedings Vol. 127, pp. 887-896.

Bruno, J., and Sandino, A. (1989) The solubility of amorphous and crystalline schoepite in neutral to alkaline aqueous solutions. In: Scientific Basis for Nuclear Waste Management XII, Materials Research Society Symposium Proceedings Vol. 127, pp. 871-878. 
Brusilovskii, S. A. (1958) Investigation of the precipitation of hexavalent uranium hydroxide. Proc. Acad. Sci. USSR, Chem. Sect. 120, 343-347.

Chukhlantsev, V. G., and Stepanov, S. I. (1956) Solubility of uranyl and thorium phosphates. Russ. J. Inorg. Chem. 1 (3), 135-141.

Clark, D. L., Hobart, D. E., and Neu, M. P. (1995) Actinide carbonate complexes and their importance in actinide environmental chemistry. Chem. Rev. 95, 25-48.

Cohen-Adad, R., Lorimer, J. W., Phillips, S. L., and M. Salomon, M. (1995) A consistent approach to tabulation of evaluated solubility data: application to the binary systems $\mathrm{RbCl}-\mathrm{H}_{2} \mathrm{O}$ and $\mathrm{UO}_{2}\left(\mathrm{NO}_{3}\right)_{2}-\mathrm{H}_{2} \mathrm{O}$, J. Chem. Information Comp. Sci. 35, 675-696.

Davydov, Yu. P. (1967) Solubility product of metal hydroxides. Sov. Radiochem. 9, 50-54.

Deichman, E. N., and Tananaev, I. V. (1962) Plutonium fluorides. Sov. Radiochem. 4, 56-62.

Delegard, C. H. (1987) Solubility of $\mathrm{PuO}_{2} \cdot \mathrm{xH}_{2} \mathrm{O}$ in alkaline Hanford high-level waste solution. Radiochim. Acta 41, 11-21.

Denotkina, R. G., Moskvin, A. I., and Shevchenko, V. B. (1960) The solubility product of plutonium(IV) hydrogen phosphate and its solubility in various acids. Russ. J. Inorg. Chem. 5, 387-389.

Denotkina, R. G. and Shevchenko, V. B. (1967a) Phosphato-compounds of plutonium(VI). Russ. J. Inorg. Chem. 12, 42-45.

Denotkina, R. G. and Shevchenko, V. B. (1967b) Complex formation by plutonium(VI) with phosphate ions. Russ. J. Inorg. Chem. 12, 1237-1239. Eriksen, T. E., Ndalamba, P., Cui, D., Bruno, J., Caceci, M., and Spahiu, K. (1993) Solubility of the redox-sensitive radionuclides ${ }^{99} \mathrm{Tc}$ and ${ }^{237} \mathrm{~Np}$ under reducing conditions in neutral to alkaline solutions. Effect of carbonate. SKB Technical Report 93-18, 32 pages.

Ewart, F. T., Gore, S. J. M., and Williams, S. J. (1985) The solubility of neptunium(IV) at high pH. U. K. Atomic Energy Research Establishment, Report AERE R 11975, 8 pages; (1987) Chem. Abstr. 106: 57509j.

Ewart, F. T., Howse, R. M., Thomason, H. P., Williams, S. J., and Cross, J. E. (1986) The solubility of actinides in the near-field. In: Scientific Basis for Nuclear Waste Management IX, Materials Research Society Symposium Proceedings Vol. 50, pp. 701-708. 
Felmy, A. R., Rai, D., Schramke, J. A., and Ryan, J. L. (1989) The solubility of plutonium hydroxide in dilute solutions and in high-ionic-strength chloride brines. Radiochim. Acta 48, 29-35.

Galkin, N. P., and Stepanov, M. A. (1960) Solubility of uranium(IV) hydroxide in sodium hydroxide. Sov. J. Atomic Energy 8, 231-233.

Gayer, K. H., and Leider, H. (1955) The solubility of uranium trioxide, $\mathrm{UO}_{3} \cdot \mathrm{H}_{2} \mathrm{O}$, in solutions of sodium hydroxide and perchloric acid at $25^{\circ} . \mathrm{J}$. Am. Chem. Soc. 77, 1448-1450.

Gayer, K. H., and Leider, H. (1957) The solubility of uranium(IV) hydroxide in solutions of sodium hydroxide and perchloric acid at $25^{\circ}$. Can. J. Chem. 35, $5-7$.

Gel'man, A. D., Moskvin, A. I., and Zaitseva, V. P. (1962) Carbonate compounds of plutonyl. Sov. Radiochem. 4, 138-145.

Goldberg, R. N. (1979) Evaluated activity and osmotic coefficients for aqueous solutions: bi-univalent compounds of lead, copper, manganese, and uranium. J. Phys. Chem. Ref. Data 8, 1005-1050.

Grenthe, I., Ferri, D., Salvatore, F., and Riccio, G. (1984) Studies on metal carbonate equilibria. Part 10. A solubility study of the complex formation in the uranium(VI)-water-carbon dioxide(g) system at $25^{\circ} \mathrm{C}$. J. Chem. Soc. Dalton Trans., 2439-2443.

Grenthe, I., Fuger, J., Konings, R. J. M., Lemire, R. J., Muller, A. B., NguyenTrung, C., and Wanner, H. (1992) Chemical Thermodynamics of Uranium, H. Wanner and I. Forest editors, Nuclear Energy Agency OECD, NorthHolland, Amsterdam.

Gryzin, Yu. I., and Koryttsev, K. Z. (1967) A study of the behavior of $\mathrm{UO}_{3}$ and its hydrates in solutions with an electrode of the third kind. Russ. J. Inorg. Chem. 12, 50-53.

Haacke, D. F., and Williams, P. A. (1979) The aqueous chemistry of uranium minerals. Part I. Divalent cation zippeïte. Mineral. Mag. 43, 539-541.

Jackson, K. J. (1996) Potential activity/composition constraints on the chemical effects of adding $\mathrm{MgO}$ to the WIPP repository: $\mathrm{U}(\mathrm{VI})$. Report to the Waste Isolation Pilot Plant Project, March 13, 1996.

Karpov, V. I. (1961) The solubility of triuranyl phosphate. Russ. J. Inorg. Chem. 6, 271-272. 
Kato, Y., Kimura, T., Yoshida, Z., and Nitani, N. (1996) Solid-liquid phase equilibria of $\mathrm{Np}(\mathrm{VI})$ and of $\mathrm{U}(\mathrm{VI})$ under controlled $\mathrm{CO}_{2}$ partial pressures. Radiochim. Acta 74, 21-25.

Kim, J. I. (1986) Chemical behavior of transuranic elements in natural aquatic systems. In: Handbook on the Physics and Chemistry of the Actinides, A. J. Frecman and C. Keller editors, Elsevier, Amsterdam, Chap. 8.

Kim, J. I., and Kanellakopulos, B. (1989) Solubility products of plutonium(IV) oxide and hydroxide. Radiochim. Acta 48, 145-150.

Kim, W. H., Choi, K. C., Park, K. K., and Eom, T. Y. (1994) Effects of hypochlorite ion on the solubility of amorphous schocpite at $25^{\circ} \mathrm{C}$ in neutral to alkaline aqueous solutions. Radiochim. Acta 66/67, 45-49.

King, E. L. (1949) The solubility of plutonium(IV) phosphates and the phosphate complexes of plutonium(IV). In: The Transuranium Elements: Research Papers, G. T. Seaborg, J. J. Katz, and W. M. Manning editors, McGraw-Hill, New York, pp. 638-665.

Krupka, K. M., Rai, D., Fulton, R. W., and Strickert, R. G. (1985) Solubility data for U(VI) hydroxide and Np(IV) hydrous oxide: application of MCC-3 methodology. In: Scientific Basis for Nuclear Waste Management VIII, Materials Research Society Symposia Proceedings Vol. 44, pp. 753-760.

Langmuir, D. (1978) Uranium solution-mineral equilibria at low temperatures with applications to sedimentary ore deposits. Geochim. Cosmochim. Acta 42, 547-569.

Lemire, R. J., Boyer, G. D., and Campbell, A. B. (1993) The solubilities of sodium and potassium dioxoneptunium(V) carbonate hydrates at 30, 50 and $75^{\circ} \mathrm{C}$. Radiochim. Acta 61, 57-63.

Lemire, R. J., and Garisto, F. (1989) The solubility of U, Np, Pu, Th and Tc in a geological disposal vault for used nuclear fuel. Atomic Energy of Canada Limited, Report AECL-10009, 123 pages.

Lemire, R. J., and Tremaine, P. T. (1980) Uranium and plutonium equilibria in aqueous solutions to $200^{\circ} \mathrm{C}$. J. Chem. Eng. Data 25, 361-370.

Linke, W. F. (1965) Solubilities: Inorganic and Metal-Organic Compounds, Vol. II, fourth edition, American Chemical Society, Washington, D. C., pp. 1598-1626.

Marković, M., and Pavković, N. (1983) Solubility and equilibrium constants of uranyl(2+) in phosphate solutions. Inorg. Chem. 22, 978-982. 
Martinot, L. (1978) Actinides. In: Encyclopedia of Electrochemistry of the Elements, Vol. VIII, Marcel Dekker, New York, Chap. VIII-2.

Martinot, L., and Fuger, J. (1985) The Actinides. In: Standard Potentials in Aqueous Solution, A. J. Bard, R. Parsons, and J. Jordan editors, Marcel Dekker, New York, Chap. 21.

Marx, G., and Keiling, C. (1989) Investigation into the solubilities, sorption and migration behavior of $\mathrm{AgI}, \mathrm{CsNO}_{3}, \mathrm{Na}_{2} \mathrm{U}_{2} \mathrm{O}_{7}, \mathrm{NpO}_{2} \mathrm{OH}$ and $\mathrm{Pu}(\mathrm{OH})_{4}$ in near-field-systems. In: Scientific Basis for Nuclear Waste Management XII, Materials Research Society Symposium Proceedings Vol. 127, pp. 855-862.

Maya, L. (1983) Hydrolysis and carbonate complexation of dioxoneptunium(V) in $1.0 \mathrm{M} \mathrm{NaClO}_{4}$ at $25^{\circ} \mathrm{C}$. Inorg. Chem. 22, 2093-2095.

Merkusheva, S. A., Skorik, N. A., Kumok, V. N., and Serebrennikov, V. V. (1967) Thorium and uranium(IV) pyrophosphates. Sov. Radiochem. 9, 683685.

Moll, H., Geipel, G., Matz, W., Bernhard, G., and Nitsche, H. (1996) Solubility and speciation of $\left(\mathrm{UO}_{2}\right)_{2} \mathrm{SiO}_{4} \cdot 2 \mathrm{H}_{2} \mathrm{O}$ in aqueous systems. Radiochim. Acta 74, 3-7.

Moskvin, A. I. (1971a) Investigation of the complex formation of trivalent plutonium, americium, and curium in phosphate solutions. Sov. Radiochem. 13, 688-693.

Moskvin, A. I. (1971b) Hydrolytic behavior of neptunium (IV, V, and VI). Sov. Radiochem. 13, 700-705.

Moskvin, A. I. and Peretrukhin, V. F. (1964) Investigation of the complex formation of pentavalent neptunium in phosphoric acid solutions by the ion-exchange method. Sov. Radiochem. 6, 198-205.

Moskvin, A. I., Shelyakina, A. M., and Perminov, P. S. (1967) Solubility product of uranyl phosphate and the composition and dissociation constants of uranyl phosphato-complexes. Russ. J. Inorg. Chem. 12, 17561760 .

Moskvin, A. I., and Zaitseva, V. P. (1962) Hydrolytic behavior of plutonyl in aqueous solutions. Sov. Radiochem. 4, 63-70.

Murav'eva, I. A., Zaborenko, K. B., Nemkova, O. G., and Pin, K. D. (1964) Determination of the solubility of precipitated uranyl phosphates of alkali metals by the tracer method. Sov. Radiochem. 6, 120-123.

Musante, Y., and Porthaulte, M. (1973) Contribution a l'etude des formes hydroxylees de l'ion plutonyle. Radiochem. Radioanal. Lett. 15, 299-306. 
Nakayama, S., Yamaguchi, T., and Sekine, K. (1996) Solubility of neptunium(IV) hydrous oxide in aqueous solutions. Radiochim. Acta 74, 15-19.

Neck, V., Runde, W., Kim, J. I., and Kanellakopulos, B. (1994) Solid-liquid equilibrium reactions of neptunium(V) in carbonate solution at different ionic strength. Radiochim. Acta 65, 29-37.

Newton, T. W., and Sullivan, J. C. (1985) Actinide carbonate complexes in aqueous solution. In: Handbook on the Physics and Chemistry of the Actinides, A. J. Freeman and C. Keller editors, Elsevier, Amsterdam, Chap. 10.

Nguyen, S. N., Silva, R. J., Weed, H. C., and Andrews, J. E., Jr. (1992) Standard Gibbs free energies of formation at the temperature $303.15 \mathrm{~K}$ of four uranyl silicates: soddyite, uranophane, sodium boltwoodite, and sodium weeksite. J. Chem. Thermodyn. 24, 359-376.

Nitsche, H. (1987) Effects of temperature on the solubility and speciation of selected actinides in near-neutral solution. Inorg. Chim. Acta 127, 121-128.

Nitsche, H. (1991) Solubility studies of transuranium elements for nuclear waste disposal: principles and overview. Radiochim. Acta 52/53, 3-8.

Nitsche, H., Roberts, K., Xi, R., Prussin, T., Becraft, K., Al Mahamid, I., Silber, H. B., Carpenter, S. A., Gatti, R. C., and Novak, C. F. (1994) Long term plutonium solubility and speciation studies in a synthetic brine. Radiochim. Acta 66/67, 3-8.

Novak, C. F., Nitsche, H., Silber, H. B., Roberts, K., Torretto, P. C., Prussin, T., Becraft, K., Carpenter, S. A., Hobart, D. E., and Al Mahamid, I. (1996) Neptunium(V) and neptunium(VI) solubilities in synthetic brines of interest to the waste isolation pilot plant (WIPP). Radiochim. Acta 74, 31-36.

O'Hare, P. A. G., Lewis, B. M., and Nguyen, S. N. (1988) Thermochemistry of uranium compounds. XVII. Standard molar enthalpy of formation at 298.15 $\mathrm{K}$ of dehydrated schoepite $\mathrm{UO}_{3} \cdot 0.9 \mathrm{H}_{2} \mathrm{O}$. Thermodynamics of (schoepite + dehydrated schoepite + water). J. Chem. Thermodyn. 20, 1287-1296.

Ollila, K. (1989) Dissolution of $\mathrm{UO}_{2}$ at various parametric conditions: a comparison between calculated and experimental results. In: Scientific Basis for Nuclear Waste Management XII, Materials Research Society Symposium Proceedings Vol. 127, pp. 337-342. 
Ollila, K., Olin, M., and Lipponen, M. (1996) Solubility and oxidation state of uranium under anoxic conditions ( $\mathrm{N}_{2}$ atmosphere). Radiochim. Acta 74, 913.

Parks, G. A., and Pohl, D. C. (1988) Hydrothermal solubility of uraninite. Geochim. Cosmochim. Acta 52, 863-875.

Pashalidis, I., Runde, W., and Kim, J. I. (1993) A study of solid-liquid phase equilibria of $\mathrm{Pu}(\mathrm{VI})$ and $\mathrm{U}(\mathrm{VI})$ in aqueous carbonate systems. Radiochim. Acta 61, 141-146.

Patil, S. K., Ramakrishna, V. V., and Ramaniah, M. V. (1978) Aqueous coordination complexes of neptunium. Coord. Chem. Rev. 25, 133-171.

Pérez-Bustamante, J. A. (1965) Solubility product of tetravalent plutonium hydroxide and study of the amphoteric character of hexavalent plutonium hydroxide. Radiochim. Acla 4, 67-75.

Pratopo, M. I., Moriyama, H., and Higashi, K. (1990) Carbonate complexation of neptunium(IV) and analogous complexation of ground-water uranium. Radiochim. Acta 51, 27-31.

Puigdomènech, I., and Bruno, J. (1988) Modelling uranium solubilities in aqueous solutions: Validation of a thermodynamic data base for the EQ3/6 geochemical codes. SKB Technical Report 88-21, 63 pages.

Puigdomènech, I., and Bruno, J. (1988) Plutonium solubilities. SKB Technical Report 91-04, 78 pages.

Rai, D. (1984) Solubility product of $\mathrm{Pu}(\mathrm{IV})$ hydrous oxide and equilibrium constants of $\mathrm{Pu}(\mathrm{IV}) / \mathrm{Pu}(\mathrm{V}), \mathrm{Pu}(\mathrm{IV}) / \mathrm{Pu}(\mathrm{VI})$, and $\mathrm{Pu}(\mathrm{V}) / \mathrm{Pu}(\mathrm{VI})$ couples. Radiochim. Acta 35, 97-106.

Rai, D., Felmy, A. R., and Ryan, J. L. (1990) Uranium(IV) hydrolysis constants and solubility product of $\mathrm{UO}_{2} \cdot \mathrm{xH}_{2} \mathrm{O}(\mathrm{am})$. Inorg. Chem. 29, 260-264.

Rai, D., and Ryan, J. L. (1982) Crystallinity and solubility of $\mathrm{Pu}(\mathrm{IV})$ oxide and hydrous oxide in aged aqueous suspensions. Radiochim. Acta 30, 213-216.

Rai, D., and Ryan, J. L. (1985) Neptunium(IV) hydrous oxide solubility under reducing carbonate conditions. Inorg. Chem. 24, 247-251.

Rai, D., Serne, R. J., and Swanson, J. L. (1980) Solution species of plutonium in the environment. J. Environ. Qual. 9, 417-420.

Rai, D., Swanson, J. L., and Ryan, J. L. (1987) Solubility of $\mathrm{NpO}_{2} \cdot \times \mathrm{IH}_{2} \mathrm{O}(\mathrm{am})$ in the presence of $\mathrm{Cu}(\mathrm{I}) / \mathrm{Cu}(\mathrm{II})$ redox buffer. Radiochim. Acta 42, 35-41. 
Rard, J. A. (1989) The effect of precipitation conditions and aging upon characteristics of particles precipitated from aqueous solutions. Lawrence Livermore National Laboratory, Report UCID-21755, 18 pages.

Red'kin, A. F., Ivanov, I. P., and Omel'yanenko, B. I. (1988) Solubility of uranium dioxide in acidic chloride fluids at $400-600^{\circ} \mathrm{C}$ and $1 \mathrm{kbar}$. Dokl. Acad. Sci. USSR, Earth Sci. Sect. 299, 240-242.

Rees, J. H. (1985) The theoretical derivation of solubilities of long-lived radionuclides in disposal. J. Nucl. Mater. 130, 336-345.

Roberts, K. E., Silber, H. B., Torretto, P. C., Prussin, T., Becraft, K., Hobart, D. E., and Novak, C. F. (1996) The experimental determination of the solubility product for $\mathrm{NpO}_{2} \mathrm{OH}$ in $\mathrm{NaCl}$ solutions. Radiochim. Acta 74, 27-30.

Robouch, P., and Vitorge, P. (1987) Solubility of $\mathrm{PuO}_{2}\left(\mathrm{CO}_{3}\right)$. Inorg. Chim. Acta 140, 239-242.

Ryan, J. L., and Rai, D. (1983) The solubility of uranium(IV) hydrous oxide in sodium hydroxide solutions under reducing conditions. Polyhedron 2, 947952.

Schmidt, V. S., Andryushin, V. G., Teterin, E. G., and Shesterikov, N. N. (1981) Plutonium(IV) hydroxynitrates. Sov. Radiochem. 23, 185-190.

Schreyer, J. M. (1955) The solubility of uranium(IV) orthophosphates in phosphoric acid solutions. J. Am. Chem. Soc. 77, 2972-2974.

Schreyer, J. M., and Baes, C. F., Jr. (1954) The solubility of uranium(VI) orthophosphates in phosphoric acid solutions. J. Am. Chem. Soc. 76, 354357.

Secoy, C. H. (1948) The system uranyl sulfate-water. I. Temperatureconcentration relationships below $300^{\circ}$. J. Am. Chem. Soc. 70, 3450-3452.

Secoy, C. H. (1950) The system uranyl sulfate-water. II. Temperatureconcentration relationships above $250^{\circ}$. J. Am. Chem. Soc. 72, 3343-3445.

Sergeyeva, E. I., Nikitin, A. A., Khodakovskiy, I. L., and Naumov, G. B. (1972) Experimental investigation of equilibria in the system $\mathrm{UO}_{3}-\mathrm{CO}_{2}-\mathrm{H}_{2} \mathrm{O}$ in $25-$ $200{ }^{\circ} \mathrm{C}$ temperature interval. Geochem. Inter. 9, 900-910.

Sevost'yanova, E. P., and Khalturin, G. V. (1976) Hydrolytic behavior of neptunium(V). Sov. Radiochem. 18, 738-743.

Silber, II. B., Nitsche, H., Gatti, R., Gehmecker, H., Feige, G., Bucher, J., and Edelstein, N. (1994) The effects of radiolysis upon speciation and solubility of neptunium in brine solutions. Radiochim. Acta 66/67, 15-18. 
Simakin, G. A. (1977) Real oxidation potentials of the couples $\mathrm{AmO}_{2}^{2+}-\mathrm{AmO}_{2}^{+}$, $\mathrm{NpO}_{2}^{2+}-\mathrm{NpO}_{2}^{+}$in solutions of potassium and sodium carbonates. Sov.

Radiochem. 19, 424-426.

Stepanov, M. A., and Galkin, N. P. (1962) Solubility product of basic uranium(IV) sulphate. Russ. J. Inorg. Chem. 7, 506-508.

Tremaine, P. R., Chen, J. D., Wallace, G. J., and Boivin, W. A. (1981) Solubility of uranium (IV) oxide in alkaline aqueous solutions to $300^{\circ} \mathrm{C}$. J. Solution. Chem. 10, 221-230.

Ueno, K., and Saito, A. (1975) Solubility and absorption spectra of a carbonato complex of pentavalent neptunium. Radiochem. Radioanal. Lett. 22, 127133.

Veselý, V., Pekárek, V., and Abbrent, M. (1965) A study on uranyl phosphates-III. Solubility products of uranyl hydrogen phosphate, uranyl orthophosphate and some alkali uranyl phosphates. J. Inorg. Nucl. Chem. 27, 1159-1166.

Visyashcheva, G. I., Volkov, Yu. F., Simakin, G. A., Kapshukov, I. I., Bevz, A. S., and Yakovlev, G. N. (1974) Carbonate compounds of pentavalent actinides with alkali metal cations. I. Composition and some properties of solid carbonates of pentavalent neptunium with potassium obtained from $\mathrm{K}_{2} \mathrm{CO}_{3}$ solutions. Sov. Radiochem. 16, 832-837.

Weigel, F., Katz, J. J., and Seaborg, G. T. (1986) Plutonium. In: The Chemistry of the Actinide Elements, Second edition, J. J. Katz, G. T. Seaborg, and L. R. Morss editors, Chapman and Hall, London, Chap. 7.

Yamaguchi, T., Sakamoto, Y., and Ohnuki, T. (1994) Effects of the complexation on solubility of $\mathrm{Pu}(\mathrm{IV})$ in aqueous carbonate system. Radiochim. Acta 66/67, 9-14. 


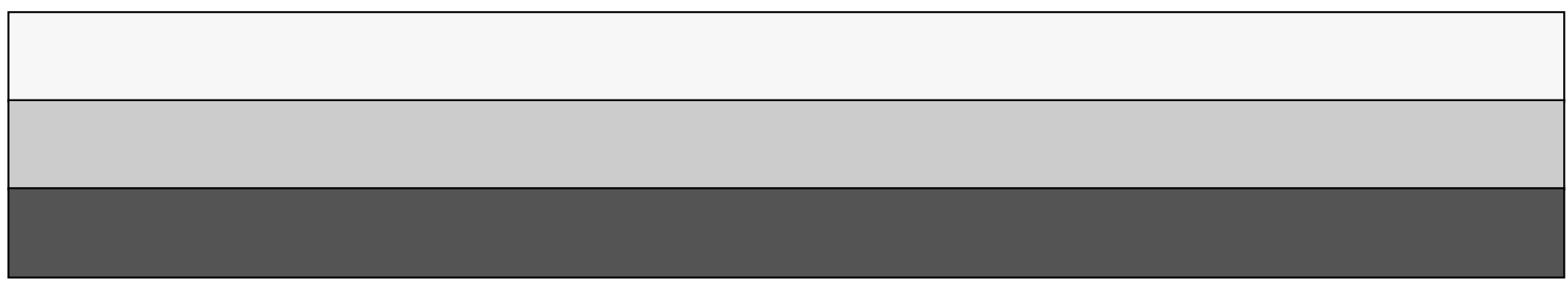

